\title{
WHO DETERMINES CUSTOMER PROPERTY
}

\begin{abstract}
Mariel Mok*
Title II of the Dodd-Frank Wall Street Reform and Consumer Protection Act gives the government the Orderly Liquidation Authority ("OLA") to seek the liquidation of failing financial companies with the appointment of the Federal Deposit Insurance Corporation ("the FDIC") as receiver. When applied to securities broker-dealers, the OLA calls into question the incorporation of the Securities Investor Protection Act of 1970 ("SIPA") that provides for the orderly liquidation of an insolvent broker-dealer under the oversight of the Securities Investor Protection Corporation ("the SIPC"). The result is a conflict of control between the FDIC and the SIPC in the event of an OLA broker-dealer liquidation and investor uncertainty regarding the incorporation of SIPA protections for customer property. Problematically, the OLA and its implementing rules leave the FDIC with discretion to modify SIPA protections for customer property.
\end{abstract}

I. Introduction

II. Background Information

A. How We Got Here

B. Securities Investor Protection Act

1. Liquidation of a Broker-Dealer Under SIPA ..695

2. SIPC's Priorities and the Importance of "Customer" and "Customer Property". 698

C. Dodd-Frank and the Orderly Liquidation Authority

1. Liquidation Under OLA 702

* J.D. Candidate 2021, Columbia Law School; B.F.A. 2015, New York University. Many thanks to Professor Ronald Mann for his guidance throughout the Note-writing process and to Roy Haynes for his comments and suggestions. My sincerest gratitude to the staff and editorial board of the Columbia Business Law Review for their assistance in preparing this Note for publication. 
2. What Broker-Dealers Would Actually Go Under OLA?

III. Conflict of Control Between the SIPC and FDIC .706

A. Difficulty of Making "Customer Property"

Determinations 708

B. Overlapping Authority of the SIPC and FDIC under

OLA.... 712

C. Ambiguity of the Proposed Rules Implementing

OLA 715

1. Who Determines "Customer Property"?

D. Treasury Report on OLA and the Current Status of

Reform 720

IV. Resolving the Conflict of Control Between FDIC and SIPC .723

A. The Looming Financial Crisis and the Need for Certainty .723

1. Avoiding Runs on Broker-Dealers. 726

B. Competing Priorities of FDIC and SIPC...............729

C. How Much Discretion is Too Much Discretion?....736

V. Conclusion .742

\section{INTRODUCTION}

The division of regulatory responsibility for financial institutions and financial products once relied on clear categorical distinctions made along industry lines. ${ }^{1}$ But the financial world of the twentieth century is now far off in our collective rearview mirror. Distinctions that were once clear-between banks and broker-dealers, and between securities and banking products-are now blurred. ${ }^{2}$ With the rise of fintech, ${ }^{3}$ the

1 See Saule T. Omarova, New Tech v. New Deal: Fintech as a Systemic Phenomenon, 36 YALE J. REG. 735, 748 (2019); Jonathan R. Macey, The Business of Banking: Before and After Gramm-Leach-Bliley, 25 J. CoRP. L. 691, 710 (2000) (describing the entity approach to regulation of financial institutions).

2 Macey, supra note 1 , at 710.

3 The term "fintech" as used in this Note refers to a variety of digital technologies applied to the provision of financial services, or, more generally, technological development in the financial sector. 
integration of banking and brokerage services, and systemic risk increases, regulatory authority in the financial services industry has been made even more ambiguous.

This Note argues that the Securities Investor Protection Corporation ("the SIPC") should retain full authority to make final determinations on what constitutes customer property eligible for protection under the Securities Investor Protection Act of 1970 ("SIPA") in a broker-dealer liquidation pursuant to the Orderly Liquidation Authority ("OLA") provisions ${ }^{4}$ of the Dodd-Frank Wall Street Reform and Consumer Protection Act ("Dodd-Frank," or "the Dodd-Frank Act"). Proposed rules implementing the OLA fail to resolve the conflict of control between the Federal Deposit Insurance Corporation ("the FDIC") and the SIPC that would result in the event of an OLA broker-dealer liquidation and inappropriately grant the FDIC discretion to determine whether SIPA protections would apply in such a case. ${ }^{5}$ This impacts investor confidence and permits the FDIC to ignore years of SIPC precedent for the sake of its own interests.

Part II of this Note presents the two ways a liquidation of a broker-dealer may be conducted-under SIPA or under OLA - and the priorities of each regime. Part III analyzes the overlapping authority of the FDIC and SIPC under the OLA, and how the Proposed Rules leave the FDIC with discretion to overrule SIPC's determinations regarding customer property. While the Proposed Rules clarify to some extent the

4 In this note, OLA refers both to the provisions in Title II of DoddFrank and the authority created by those provisions.

5 During the final stages of editing this note, the Proposed Rules discussed here became final after four years of agency inaction. See Press Release, Fed. Deposit Ins. Corp., Agencies Adopt Final Rule on the Orderly Liquidation of Covered Broker-Dealers under Title II of the Dodd-Frank Act (July 24, 2020), https://www.fdic.gov/news/press-releases/2020/pr20088.html [https://perma.cc/P7LS-2LY9]. The final rule is substantively identical to the Proposed Rules and will be effective 60 days after publication in the Federal Register. See id. It is fitting that a decade after Dodd-Frank's passage, and as we are living through a global recession, the government is are solidifying its response to the last recession. Where so much of life is up in the air, predictability is all the more important, and we can only hope the broker-dealer resolution process is one area where the path forward is clear. 
regulatory roles of the FDIC and SIPC, they do not sufficiently clarify those roles. ${ }^{6}$ Moreover, the Proposed Rules-because of the discretion they give the FDIC-leave it unclear as to whether customers will receive the protections guaranteed by SIPA in the event of a broker-dealer liquidation conducted pursuant to the OLA. Part IV suggests that the ambiguity surrounding the division of authority between the FDIC and SIPC needs to be resolved, especially as the rise of fintech further blurs the line between banks and brokerage firms and heightens systemic risk. Part IV further suggests that in light of the SIPC's experience and established public record of making customer property determinations, as well as the political pressures the FDIC might face when making such determinations, the SIPC should make final determinations of what constitutes customer property in OLA liquidations of broker-dealers.

\section{BACKGROUND INFORMATION}

\section{A. How We Got Here}

When the New York Stock Exchange collapsed in 1929, many ordinary working-class citizens suffered great losses, with some losing their entire savings. ${ }^{7}$ Public panic in the days after the stock market crash led to "bank runs," where hordes of people rushed to banks to withdraw all their funds. ${ }^{8}$ This led to massive bank failures and resulted in an almost total collapse of the nation's banking system. ${ }^{9}$

The subsequent Great Depression shaped the New Deal era of financial services regulation. In order to restore depositor confidence in the banking system and stimulate economic growth, Congress established the federal deposit insurance

6 See infra Section III.C.

7 Sara Hsu, Financial Crises, 1929 to the Present 20 (2d ed. 2017).

8 Id.

9 See FAIC Secs., Inc. v. United States, 768 F.2d 352, 354 (D.C. Cir. 1985). 
system in 1933.10 The Glass-Steagall Act ("Glass-Steagall") created the FDIC and institutionalized the federal government's role as a market backstop. ${ }^{11}$ By insuring deposits, the FDIC provides a public safety net and prevents panic-induced bank runs. Glass-Steagall also imposed a legal separation on the commercial and investment banking industries. ${ }^{12}$

The New Deal era regulations made great strides to restore confidence in the banking system, ${ }^{13}$ but a new regulatory challenge arose during the 1960s. That decade saw a significant rise in the stock market, with the participation of new investors who had previously avoided stocks. ${ }^{14}$ When widespread broker-dealer failures occurred in the late 1960s, customers collectively lost over $\$ 100$ million in assets, including losses attributable to securities that had been fully paid for. ${ }^{15}$ The failures of broker-dealers revealed that customer property had been routinely misappropriated, and that broker-dealers maintained an insufficient level of capital. ${ }^{16}$ As confidence in brokerage accounts declined, Congress responded by passing the Securities Investor Protection Act of 1970 to protect individual investors from financial hardship, increase the financial responsibility of broker-dealers, and eliminate the risks

10 See Banking Act of 1933, Pub. L. No. 73-66, 48 Stat. 162 (codified as amended in scattered sections of 12 U.S.C.).

11 See id. The authority of the FDIC was made permanent with the passage of the Banking Act of 1935. See Pub. L. No. 74-305, 49 Stat. 684 (codified as amended in scattered sections of 12 U.S.C.). The statutory provisions that currently govern the FDIC were enacted in the Federal Deposit Insurance Act of 1950. See Pub. L. No. 81-797, 64 Stat. 873 (1950) (codified as amended at 12 U.S.C. $\S \S 1811-1835 a(2018))$.

12 Macey, supra note 1, at 691.

13 Thad Grundy, Jr., Practical Aspects of the Deposit Insurance System, 44 Bus. LAW. 169, 170 (1988).

14 See Wyatt Wells, Certificates and Computers: The Remaking of Wall Street, 1967 to 1971, 74 Bus. HIsT. REV. 193, 194-95 (2000) (noting that in 1952, only 6.5 million Americans owned stocks, and by 1965, that number was over 20 million).

15 See Ian J. Combs, Central Role of Finance and Operations, in GovERnance, Compliance, And Supervision in the Capital Markets 99, 115 (Sarah Swammy \& Michael McMaster eds., 2018).

16 See Note, The Securities Investor Protection Act of 1970: An Early Assessment, 73 Colum. L. REV. 802, 802-04 (1973). 
that lead to customer losses. ${ }^{17}$ SIPA empowered the Securities and Exchange Commission ("the SEC") to establish financial responsibility rules for broker-dealers and created the Securities Investor Protection Corporation to carry out SIPA's new procedures for liquidating financially troubled broker-dealers. ${ }^{18}$

As the sun set on the twentieth century, Congress enacted the Gramm-Leach-Bliley Act of 1999 ("Gramm-Leach-Bliley"). ${ }^{19}$ Gramm-Leach-Bliley repealed Glass-Steagall, thus collapsing the regulatory wall that previously separated investment banks and commercial banks. ${ }^{20}$ As lines between the trading activities of commercial banks and broker-dealers faded during the early 2000 s, commercial banks and their affiliates began to compete head-to-head with broker-dealers, using their lending relationships and ability to access capital at relatively low cost to gain substantial market share in traditional investment bank businesses. ${ }^{21}$

17 Securities Investor Protection Act of 1970, Pub. L. No. 91-598, 84 Stat. 1636 (codified as amended at 15 U.S.C. $\S \S 78$ aaa-lll (2018)). See also The Subject of Deposit Insurance Reform as well as the Necessary Related Subject of Financial Institutions Supervision and to Determine the Problems and Strengths in the Current Structures: Hearings Before the S. Comm. on Banking, Hous., \& Urban Affairs, 99th Cong. 32 (1986) (statement of Theodore H. Focht, President \& General Counsel, Securities Investor Protection Corporation).

18 Securities Investor Protection Act of 1970, Pub. L. No. 91-598, §§ 3(a), 7(d), 84 Stat. 1636, 1637, 1653 (amending section 15(c)(3) of the Securities Exchange Act of 1934).

19 Gramm-Leach-Bliley Act, Pub. L. No. 106-102, 113 Stat. 1338 (1999) (codified as amended in scattered sections of 12 U.S.C.).

20 See id. See also Macey, supra note 1, at 709. However, the line between commercial and investment banking had already started blurring before Gramm-Leach-Bliley Act passed. See id. at 691-92 ("[T]he GlassSteagall Act was already a dead letter when Gramm-Leach-Bliley was passed. All the Act did was to formalize the death."). See 145 ConG. REC. S13890 (daily ed. Nov. 4, 1999) (statement of Sen. Bryan) ("[T]he financial regulatory structure that emerged as a consequence of the Great Depression, the Glass-Steagall Act, no longer comports with the reality of the marketplace.").

21 See Charles K. Whitehead, Size Matters: Commercial Banks and the Capital Markets, 76 OHIо ST. L.J. 765, 775-76 (2015). 
Then came the 2008 financial crisis and the subsequent reversal of the prior decade's regulatory direction. ${ }^{22}$ Many major financial institutions were in dire straits as mortgage-backed securities, composed of risky subprime mortgages, suffered immense losses. ${ }^{23}$ Under stress, Bear Stearns (the fifth-largest U.S. bank) and Lehman Brothers (the fourth-largest U.S. bank) were forced to merge. ${ }^{24}$ Other "too big to fail" financial institutions filed for bankruptcy, while still others received government bailouts. ${ }^{25}$ In response, Congress passed the Dodd-Frank Wall Street Reform and Consumer Protection Act. ${ }^{26}$ Aimed at protecting systemic financial stability, DoddFrank reemphasized the role of public actors in the financial markets, recalling the goals of the New Deal. ${ }^{27}$

Reeling from the public outcry over taxpayer-funded bailouts, Congress designed Dodd-Frank to avoid similar future interventions. In particular, under its second title Congress established a regime for resolving large, complex financial companies. ${ }^{28}$ This resolution tool, the Orderly Liquidation Authority, was intended to function as an alternative to potentially destabilizing bankruptcies and taxpayer-funded bailouts. ${ }^{29}$ This approach built on earlier practice; federal law has long provided a specialized insolvency regime for

22 Fin. CRisis Inquiry COMM'N, The Financial CRISIS Inquiry REPORT xvi (2011) [hereinafter FCIC REPORT].

23 Id.

24 See id. at xix-xxi.

25 See id. A government bailout involves injecting liquidity into a failing firm to avoid the ramifications of that firm's failure. See Emergency Economic Stabilization Act of 2008, Pub. L. No. 110-343, § 2(1), 122 Stat. 3765, 3766 (providing authority to the government to purchase and insured certain troubled assets "to restore liquidity and stability to the financial system").

26 Dodd-Frank Wall Street Reform and Consumer Protection (DoddFrank) Act, Pub. L. No. 111-203, 124 Stat. 1376 (2010) (codified in scattered sections of 12 and 15 U.S.C.).

27 See generally David Skeel, The New Financial Deal: UnderstandING THE DoDD-Frank ACT AND ITs (UNINTENDED) CONSEQUENCES (2010).

28 Dodd-Frank Act $\S \S 201-217$.

29 See U.S. DeP'T OF TREASURY, ORDERLy LiQUidation AUTHORITY AND BANKRUPTCY REFORM 31 (2018), https://home.treasury.gov/sites/default/files/2018-02/OLA_REPORT.pdf [https://perma.cc/NY66-U85B]. 
depository institutions and broker-dealers under the Federal Deposit Insurance Act ("the FDIA") and SIPA, respectively. Accordingly, Congress split the authority for OLA liquidations between the FDIC and SIPC. ${ }^{30}$

But the powers granted to the FDIC create a conflict with the powers granted to SIPC to administer the liquidation of a failing broker-dealer under SIPA. ${ }^{31}$ Combined with an unclear OLA process, the overlapping authority of the FDIC and SIPC has generated confusion in the market as to what would happen in the event of a broker-dealer default. ${ }^{32}$ Acknowledging the potentially conflicting authority of the FDIC and SIPC, the SEC and FDIC (collectively, "the Agencies") jointly issued a Notice of Proposed Rulemaking ("the Proposed Rules") to implement the OLA. ${ }^{33}$ Stalled under the deregulatory agenda of the Trump administration, however, the Proposed Rules, which were intended to fill the gaps of OLA, have yet to become final, leaving the prospect of a broker-dealer insolvency in a precarious state even ten years after the enactment of Dodd-Frank.

\section{B. Securities Investor Protection Act}

Congress enacted SIPA in response to a series of insolvencies among broker-dealers during the late 1960s. ${ }^{34}$ Clients of failing broker-dealers ${ }^{35}$ lost access to their property and

30 See infra Sections IV.B-C.

31 See 15 U.S.C. $\S \S 78 f f f-78 f f f-4$ (2018).

32 See e.g., Stephen J. Lubben, Sorting Out Dodd-Frank's Treatment of Failed Broker-Dealers, N.Y. TIMES (Feb. 25, 2016), https://www.nytimes.com/2016/02/26/business/dealbook/sorting-out-dodd-franks-treatment-of-failed-broker-dealers.html [https://perma.cc/2DDB-X69L].

33 See Covered Broker-Dealer Provisions Under Title II of the DoddFrank Wall Street Reform and Consumer Protection Act, 81 Fed. Reg. 10,798 (proposed Mar. 2, 2016) (to be codified at 12 C.F.R. pt. 380 and 17 C.F.R. pt. 302).

34 See S. REP. No. 91-1218, at 2-3 (1970).

35 This Note refers to customers of a broker-dealer as "clients" to avoid confusion with the statutory definition of a "customer" of a "covered broker or dealer.” See 12 U.S.C. § 5381(a)(7), § 5381(a)(10) (2018). Under SIPA and OLA, "customer" and "customer property" are defined terms. See 12 U.S.C. $\S 5381(\mathrm{a})(10)$; 15 U.S.C. $\S 78 l l l(2)-(4)$. Whether these definitions are met is 
suffered heavy losses, which weakened confidence in the securities markets. ${ }^{36}$ Existing safeguards did not adequately protect clients, since broker-dealers frequently commingled clients' assets with their own and bankruptcy proceedings to recover assets could take years. ${ }^{37}$

Congress had two goals in passing SIPA. First, it sought to "provide protection for investors if the broker-dealer with whom they are doing business encounter[ed] financial troubles." 38 Vindication of a customer's right to receive the securities for which he paid in full was a cornerstone of this protection. ${ }^{39}$ Second, Congress hoped to increase the general public's confidence in the securities industry. ${ }^{40}$ To fulfill these purposes, SIPA targeted the risks that led to investor losses by placing additional financial responsibility requirements on broker-dealers, and creating special procedures for the liquidation of failed broker-dealers. ${ }^{41}$ Under SIPA liquidation proceedings, a SIPA trustee administers "what is in effect a 'bankruptcy within a bankruptcy' for investors who had property on account with the [failed] broker-dealer." ${ }^{2}$

SIPA also created the SIPC to implement some of its provisions. The SIPC is a private, nonprofit membership corporation to which most registered brokers and dealers must

crucial for a client's eligibility for SIPA protections, and the priority of a client's claims in liquidation proceedings. See 15 U.S.C. § 78fff(a)(1), 78fff (c)-(d). Although this Note refers to the general protections for brokerdealer clients and client property under SIPA, such protections would only apply to "customers" and to "customer property." Where "customer" or "customer property" are used in this Note, reference is made to the defined terms under SIPA.

36 H.R. REP. No. 91-1613, at 2 (1970), as reprinted in 1970 U.S.C.C.A.N. 5254,5255 .

37 Id. at $2-3$.

38 Id. at 1.

39 Id.

40 Id. at 2. See also Secs. Inv'r Prot. Corp. v. Barbour, 421 U.S. 412, 415 (1975) ("Congress enacted the SIPA to . . restore investor confidence in the capital markets ....”).

41 See H.R. REP. No. 91-1613, at 4, 8-9; see also 15 U.S.C. §§ 78fff, $780(c)(3)$ (2018).

42 In re Lehman Bros., Inc., 791 F.3d 277, 281 (2d Cir. 2015). 
belong. ${ }^{43}$ Broker-dealer members pay an assessment into a liquidation insurance fund administered by the SIPC. A key power of the SIPC is its power to promulgate rules relating to "the procedures for the liquidation of members and direct payment procedures, including the transfer of customer accounts, the distribution of customer property, and the advance and payment of SIPC funds." 44

\section{Liquidation of a Broker-Dealer Under SIPA}

In the event that a broker-dealer fails, eligible clients of the broker-dealer are entitled to protections provided under SIPA. ${ }^{45}$ If the failing broker-dealer is a SIPC member, then the SIPC may seek the appointment of a trustee (which may be itself, under limited circumstances) to liquidate the failed firm. ${ }^{46}$ A SIPC-managed liquidation is an alternative proceeding to a Chapter 7 bankruptcy for broker-dealers, ${ }^{47}$ though both Chapter 7 bankruptcy proceedings and SIPA liquidations favor broker-dealer customers over general creditors. ${ }^{48}$

A liquidation under SIPA may have as many as four stages. First, the appointed trustee of the SIPC may arrange

4315 U.S.C. $\S \S 78 c c c(a)(1)-(2)$. Specifically, broker-dealers registered under $\S 15(b)$ of the Securities Exchange Act of 1934 are required to be members of SIPC. See 15 U.S.C. $§ 780(b)$.

4415 U.S.C. $\S 78 \mathrm{ccc}(\mathrm{b})(4)(\mathrm{B})$.

45 See infra Sections II.B.2, III.C.

46 See 11 U.S.C. $\$ 742$ (2018) ("SIPC may file an application for a protective decree under the Securities Investor Protection Act of 1970. The filing of such application stays all proceedings in the case under [the bankruptcy code] . . . . If SIPC completes the liquidation of the debtor, then the court shall dismiss the case.").

47 See id. Chapter 7 of the Bankruptcy Code provides for a type of bankruptcy proceeding that involves the liquidation of a debtor's assets. See 11 U.S.C. $\S \S 781-784$. This is in contrast to the procedure of Chapter 11 of the Bankruptcy Code, which allows debtors to reorganize themselves instead of liquidating. See 11 U.S.C. $\S \S 1101-1195$. Broker-dealers are ineligible for Chapter 11 relief. See 11 U.S.C. § 109(d).

48 Thomas W. Joo, Who Watches the Watchers? The Securities Investor Protection Act, Investor Confidence, and the Subsidization of Failure, $72 \mathrm{~S}$. CAL. L. REV. 1071, 1119 (1999) ("[M] ost of the business of a liquidation [under SIPA] has great importance to the industry and its customers, and very little to do with the interests of general creditors.”). 
to have some or all customer accounts transferred to another SIPC member firm. ${ }^{49}$ In the event that is not feasible, the trustee or the SIPC will distribute "customer name securities" back to each customer. ${ }^{50}$ Second, customers receive a pro rata portion of all remaining "customer property" held by the failing firm. ${ }^{51} \mathrm{~A}$ fund of "customer property," 52 separated by the trustee from the general estate of the broker-dealer, is established for priority distribution exclusively among customers. ${ }^{53}$ This feature of SIPA strongly favors customers and provides customers with confidence that their assets are safe. The customer property fund consists of "cash and securities ... at any time received, acquired, or held" by the broker-dealer on behalf of customers (except customer name securities which have already been distributed to the customer at this stage). ${ }^{54}$ The fund of customer property is based on the claims of the

4915 U.S.C. $\S 78 f f f-2(f)$.

5015 U.S.C. $\S \S 78 f f f(a)(1)(A), 78 f f f-2(b)$. SIPA defines customer name securities as:

securities which were held for the account of a customer on the filing date by or on behalf of the debtor and which on the filing date were registered in the name of the customer, or were in the process of being so registered pursuant to instructions from the debtor, but does not include securities registered in the name of the customer which, by endorsement or otherwise, were in negotiable form.

15 U.S.C. $\S 78 l l l(3)$.

51 See 15 U.S.C. $\S \S 78 f f f(a)(1)(B), 78 f f f-2(c), 78 l l l-4$.

52 "Customer property" is defined by SIPA as:

cash and securities (except customer name securities delivered to the customer) at any time received, acquired, or held by or for the account of a debtor from or for the securities accounts of a customer, and the proceeds of any such property transferred by the debtor, including property unlawfully converted.

15 U.S.C. $§ 78 l l l(4)$. The definition contains a list of examples of "customer property." See 15 U.S.C. $\$ \S 78 l l l(4)(\mathrm{A})-(\mathrm{E})$.

53 See 15 U.S.C. $§ 78 f f f-2(c)(1)(D)$ ("Any customer property remaining after allocation in accordance with this paragraph shall become part of the general estate of the debtor.").

5415 U.S.C. $§ 78 l l l(4)$. 
customers. ${ }^{55}$ Each customer "share[s] ratably" in this fund of customer property to the extent of their net equity." ${ }^{56}$ A customer's net equity is the sum which would have been owed by the broker-dealer to the customer had the broker-dealer liquidated, less any indebtedness of the customer to the brokerdealer. ${ }^{57}$ Third, if, as is the case in many liquidations, the fund of customer property is insufficient to satisfy every customer's net equity claim, then the trustee may dip into the "SIPC Fund" to make up the shortfall. ${ }^{58}$ Administering this insurance-like fund is one of the SIPC's responsibilities under SIPA, ${ }^{59}$ and the SIPC maintains it with fee assessments on its broker-dealer members. ${ }^{60}$ In attempting to cover a shortfall, the SIPC may advance a maximum of $\$ 500,000$ (including a limit for cash claims) to each eligible securities account customer. ${ }^{61}$ The $\$ 500,000$ protection applies to any deficiencies (i) after the return of customer name securities, and (ii) after there is a pro rata distribution of customer property. ${ }^{62}$ Finally, if the funds from fee assessments become inadequate, SIPA authorizes the SIPC to borrow from the United States Treasury. ${ }^{63}$ The SIPC covers most types of securities held in client accounts, including domestic and foreign stocks, bonds, notes, and certificates of deposit. ${ }^{64}$ If there are insufficient securities

55 Under SIPA, all claims must be filed with the trustee, who is charged with determining customer claims in writing. See 15 U.S.C. § $78 \mathrm{fff}-$ 2(a)(2). Any objection of a customer to this determination must be filed with the bankruptcy court. See 15 U.S.C. $\$ 78$ eee(b)(2).

56 See 15 U.S.C. $§ 78 f f f-2(c)(1)(B)$.

57 See 15 U.S.C. $\S \S 78 l l l(11)(\mathrm{A})-(\mathrm{C})$.

58 See 15 U.S.C. $\S 78 \mathrm{ddd}(\mathrm{a}), 78 \mathrm{fff}-3(\mathrm{a})$.

59 See 15 U.S.C. $\S 78 d d d(a)(1)$.

60 See 15 U.S.C. $\S \S 78 \mathrm{ddd}(\mathrm{c})(1)-(2)$. Specifically, the fund relies on assessments on a portion of SIPC members' annual gross revenues derived from their securities business. See id.

61 See 15 U.S.C. $§ 78 f f f-3(a)$.

62 See id.

63 See 15 U.S.C. $\S \S 78 \mathrm{ddd}(\mathrm{g})-(\mathrm{h})$ (authorizing the SEC to borrow up to $\$ 2.5$ billion from the U.S. Treasury on behalf of the SIPC).

64 "Security" is a defined under SIPA. 15 U.S.C. $§ 78 l l l(14)$. Additionally, SIPC provides a list of covered instruments. See What SIPC Protects, SIPC, https://www.sipc.org/for-investors/what-sipc-protects [https://perma.cc/5882-V89P] (last visited July 15, 2020). 
to satisfy all customer claims, the SIPC may also purchase securities to make up the shortfall. ${ }^{65}$

\section{SIPC's Priorities and the Importance of "Customer" and "Customer Property"}

The SIPC describes its mission as working to return customers' cash and securities "as quickly as possible" in a liquidation under SIPA. ${ }^{66}$ In this way, the SIPC has a singular focus: to protect the customers of broker-dealers. ${ }^{67}$ Without the SIPC, investors at financially troubled brokerage firms might completely lose their securities or money, resulting in decreased confidence and willingness to invest. ${ }^{68}$

But not all investors are created equal. SIPA gives customers an unrestricted right to receive their securities. ${ }^{69}$ In a broker-dealer liquidation proceeding in accordance with SIPA, the claims of SIPA customers must be satisfied before the claims of any other entity. ${ }^{70}$ In effect, SIPA establishes a separate class of creditors called "customers" who receive "preferential protection" when a broker-dealer becomes insolvent. ${ }^{71}$

SIPA defines "customers" as those with "a claim on account of securities received, acquired, or held by the debtor ... for

6515 U.S.C. $§ 78 f f f-2(d)$.

66 See Mission, SIPC, https://www.sipc.org/about-sipc/sipc-mission [https://perma.cc/VH7J-C4UV] (last visited Mar. 12, 2020).

67 See id. ("SIPC's focus is . . narrow: restoring customer cash and securities left in the hands of bankrupt or otherwise financially troubled brokerage firms.").

68 See History and Track Record, SIPC, https://www.sipc.org/aboutsipc/history [https://perma.cc/ZN23-YG9M] (last visited Mar. 12, 2020).

69 Id.

70 See 15 U.S.C. $\$ 78 f f f-2(b)$ (under SIPA, a trustee's role is to "promptly discharge . . . all obligations of the debtor to a customer relating to, or net equity claims based upon, securities or cash ....”). See, e.g., SEC v. Kenneth Bove \& Co. Inc., 378 F. Supp. 697, 700 (S.D.N.Y. 1974); In re New Times Sec. Servs., Inc., 463 F.3d 125, 127 (2d. Cir. 2006) (drawing a distinction between customers and unprotected lenders); SEC v. S.J. Salmon \& Co. Inc., 375 F. Supp. 867 (S.D.N.Y. 1974) (client's recision claim based upon fraudulent inducement was not a SIPA customer claim; client would have to pursue claim against broker as a general unsecured creditor).

71 Kenneth Bove \& Co., 378 F. Supp. at 700. 
safekeeping, with a view to sale, to cover consummated sales, pursuant to purchases, as collateral, security, or for purposes of effecting transfer."72 If SIPA classifies an investor as a "customer," she is entitled to SIPA protections, but other investors are not. Other investors must make claims as general bankruptcy creditors, and thus are subordinate to customer claims. ${ }^{73}$ Thus enhanced protection turns on whether or not a customer has a claim on customer property. However, as will be discussed below, the SIPC has not always had an easy time classifying "customers" and "customer property."

\section{Dodd-Frank and the Orderly Liquidation Authority}

The financial crisis of 2008 revealed issues with how the government and markets deal with the failures or near-failures of large financial institutions, particularly with respect to whether distressed institutions should be bailed out or allowed to fail. Before the financial crisis, "regulators relied on a variety of prudential regulations, federal deposit insurance, and the Federal Reserve's emergency lending power to limit the risk of commercial bank failures."74 Many commentators viewed the distress and failure of a number of financial institutions during the crisis as highlighting the inadequacy of existing prudential regulations and the Bankruptcy Code. ${ }^{75}$

7215 U.S.C. $\$ 78 l l l-2(\mathrm{a})$.

7315 U.S.C. $\$ 78 f f f-2(c)(1)$. After customers are satisfied, the liquidation of the broker-dealer will continue as a normal bankruptcy proceeding, and non-customer creditors will look to the general assets of the broker-dealer for satisfaction. See id. See also Kenneth Bove \& Co., 378 F. Supp. at 700 (" $[\mathrm{P}]$ referential protection is accorded to a person who can trace and identify the trust property or funds in the hands of the stockbroker; other claimants must look to the general assets of the stockbroker for satisfaction.").

74 Jay B. SyKes, Cong. Research Serv., R45162, Regulatory REForm 10 Years After the Financial Crisis: Systemic Risk Regulation of NonBANK FINANCIAL INSTITUTIONS 1 (2018).

75 See U.S. Dep’t of Treasury, Financial Regulatory Reform: A New Foundation: Rebuilding Financial Supervision and Regulation 2-3, 8 (2009); John L. Douglas \& Randall D. Guynn, Resolution of US Banks and Other Financial Institutions, in DEBT RESTRUCTURING 311, 359 (Rodrigo Olivares-Caminal et al. eds., 2011). 
If the Bankruptcy Code was inadequate, however, there was little alternative but government bailouts. ${ }^{76}$ Facing public disapproval of spending taxpayer dollars on bailouts, the Obama administration proposed a new insolvency regime. ${ }^{77}$

Dodd-Frank was the federal government's response to the financial crisis of 2008. ${ }^{78}$ Title II of Dodd-Frank-the OLAsets out procedures to govern the liquidation of a failing nonbank financial institution. ${ }^{79}$ It is designed to serve as a substitute for bankruptcies or government bailouts of financial firms deemed "too big to fail," reflecting the belief that resolution of a large financial firm under the Bankruptcy Code or existing insolvency regulations "would threaten the stability of the financial markets." 80 The OLA thus provides an alternative insolvency regime for "failing financial companies that pose a significant risk to the financial stability of the United States." 11 The OLA also includes provisions specific to "covered broker[s] or dealer[s]," 82 which is defined as a covered

76 See S. REP. No. 111-176, at 43 (2010) ("With no other means to resolve large, complex and interconnected financial firms, the government was left with few options other than to provide massive assistance to prop up failing companies in an effort to prevent the crisis from spiraling into a great depression.”).

77 See President Barack Obama, Address in the East Room on Regulatory Reform (June 17, 2009), https://obamawhitehouse.archives.gov/thepress-office/remarks-president-regulatory-reform/ [https://perma.cc/5F9HGNA2] (referencing the lack of "any effective system in place to contain the failure of an AIG" in proposing a "resolution authority' for large and interconnected financial firms"). See also Press Release, The White House, President Obama to Announce Comprehensive Plan for Regulatory Reform, (June 17, 2009), https://obamawhitehouse.archives.gov/the-press-office/president-obama-announce-comprehensive-plan-regulatory-reform [https://perma.cc/MA9V-CUQ3]; U.S DEP'T OF TREASURY, supra note 75.

78 Dodd-Frank Act, Pub. L. No. 111-203, 124 Stat. 1376 (2010) (codified in scattered sections of 12 and 15 U.S.C.).

79 Id. $\S \S 201-217$.

80 See Thomas W. Merrill \& Margaret L. Merrill, Dodd-Frank Orderly Liquidation Authority: Too Big for the Constitution?, 163 U. PA. L. REV. 165, 174 (2014).

81 Dodd-Frank Act $\S 204(\mathrm{a})$.

82 Id. $\S \S 206,210(\mathrm{a})(1)(\mathrm{O}), 210(\mathrm{~b})(6), 210(\mathrm{~d})(3)$. 
financial company that is registered with the SEC as a broker or dealer and is a member of the SIPC. 83

An OLA liquidation of a financial company must begin with a written recommendation from the FDIC and Federal Reserve. ${ }^{84}$ Upon receiving such recommendation, the Treasury Secretary, in consultation with the President, determines whether the company poses a systemic risk meriting liquidation under the OLA. ${ }^{85}$ To make this determination, the Treasury Secretary is required to evaluate the financial company's state of distress and the potential adverse effects of the company's bankruptcy on U.S. financial stability. ${ }^{86}$ The enumerated factors guiding this determination are listed below:

[1] the company is in default or in danger of default; [2] the failure of the company and its resolution under otherwise applicable federal or state law (i.e. the Bankruptcy Code) would have serious adverse effects on U.S. financial stability; [3] no viable private sector alternative is available to prevent the default of the company; [4] any effect on the claims or interests of creditors, counterparties, and shareholders of the company and other market participants as a result of actions to be taken under OLA is appropriate, given the impact that any action taken under OLA would have on U.S. financial stability; [5] any action taken under OLA would avoid or mitigate such adverse effects; [6] a federal regulatory agency has ordered the financial company to convert all of its convertible debt instruments that are subject to the regulatory order, and [7] the company satisfies the definition of "financial company. 87

Both these criteria and the requirement of approval by various parties work to ensure that the OLA will only be invoked if a failing firm poses a serious threat to the financial stability

8312 U.S.C. $\S 5381(\mathrm{a})(7)$ (2018).

8412 U.S.C. $\S 5383(\mathrm{a})$. The recommendation must be supported by a vote of two-thirds of the directors of the FDIC and two-thirds of the members of the Board of Governors of the Federal Reserve System. See id.

8512 U.S.C. $\$ 5383$.

86 Id.

87 Id. 
of the United States. Further, the decision to invoke the OLA is subject to limited, expedited judicial review. ${ }^{88}$

\section{Liquidation Under OLA}

If the OLA is invoked, the covered broker-dealer is placed into an orderly liquidation proceeding. With this determination, the FDIC is appointed receiver of the failing firm, ${ }^{89}$ and "assumes responsibility for efficiently recovering the maximum amount possible from the disposition of the receivership's assets." 90 More generally, administrative receiverships of FDIC-insured banks provide the model for the OLA process. ${ }^{91}$ As receiver, the FDIC succeeds "all rights, titles, powers, and privileges of the . . company and its assets, and of any stockholder, member, officer or director." 92 The FDIC may continue the company's business and liquidate or wind-up its affairs "in such manner as [it] deems appropriate." 93 Moreover, the FDIC may sell the firm's assets to amass funds, merge the firm with another company, or transfer the firm's assets or liabilities to another company or a new FDIC-created "bridge financial company."94

Despite its numerous powers, the FDIC nevertheless splits its authority with the SIPC. In a liquidation of a covered broker-dealer under OLA, the FDIC would appoint the SIPC to "act as trustee for the liquidation under [SIPA] of the covered

88 See 12 U.S.C. $§ 5382(\mathrm{a})(1)(\mathrm{A})(\mathrm{i})$.

89 See 12 U.S.C. $\$ 5384$.

90 Receivership Management Program, FDIC (Jan. 29, 2018), https://www.fdic.gov/about/strategic/strategic/receivership.html [https://perma.cc/ZG3Z-7BVU].

91 See id.

92 Dodd-Frank Act, Pub. L. No. 111-203, § 210(a)(1)(A)(i), 124 Stat. 1376, 1460 (2010) (codified at 12 U.S.C. § 5390(a)(1)(A) (2018)).

$93 \quad I d . \S 210(\mathrm{a})(1)(\mathrm{D})$.

94 See id. $\S 210(\mathrm{a})(1)(\mathrm{D})-(\mathrm{G})$. A bridge financial company is a new financial company that may be organized by the FDIC for the purposes of resolving the failing company. See $i d$. $\S 201(a)(3)$. It may assume liabilities or purchase assets of the failing company, and perform any other function at the FDIC's discretion. See id. $\S 210(\mathrm{~h})(1)(\mathrm{B})$. OLA includes provisions specific to bridge broker-dealers. See id. $\S 210(\mathrm{~h})(2)(\mathrm{H})$. 
broker or dealer."95 The SIPC would have all of the powers and duties provided to it by SIPA, including rights of action against third parties. ${ }^{96}$ The SIPC is to "conduct [the] liquidation in accordance with the terms of [SIPA]," with an exception for "assets and liabilities transferred by the [FDIC] from the covered broker or dealer to any bridge financial company." 97

The OLA was politically controversial. Some argued it would institutionalize government bailouts, while others insisted it would put an end to bailouts altogether. ${ }^{98}$ Much of the debate stems from the FDIC's responsibility to balance two competing interests under the OLA. ${ }^{99}$ Congress designed the OLA to allocate the losses of a failing firm to its creditors and shareholders and provided that the OLA must not provide a more generous amount to creditors than the bankruptcy process would. 100 However, Congress also sought to minimize risks to financial stability through the OLA. ${ }^{101}$ In fulfilling the latter goal, the FDIC may find it necessary to prop up a firm or protect certain creditors, in order to prevent potential systemic consequences, thus betraying the former. As the FDIC has broad discretion to balance its competing objectives, "market participants may find it difficult to predict which objective might receive more weight in any given failure."102

$95 \quad I d . \S 205(\mathrm{a})(1)$.

96 See id. §205(b)(1).

97 Id.

98 See Mark R. Maciuch, Backstop, not Bailout: The Case for Preserving the Orderly Liquidation Authority under Dodd-Frank, 13 BROOK. J. CoRP., Fin. \& CoM. L. 263, 270 (2018); Merrill \& Merrill, supra note 80, at 170.

99 Sabrina R. Pellerin \& John R. Walter, Orderly Liquidation Authority as an Alternative to Bankruptcy, 98 Econ. Q. 1, 10 (2012).

100 Dodd-Frank Act, Pub. L. No. 111-203, §§ 204(a), 210(d)(2), 124 Stat. 1376, 1454, 1494-95 (2010) (codified at 12 U.S.C. $§ \S 5384($ a), 5390(d)(2) (2018)).

101 Id. $\S \S 204(\mathrm{a}), 210(\mathrm{a})(9)(\mathrm{E})(\mathrm{iii})$.

102 See Pellerin \& Walter, supra note 99, at 10. 


\section{What Broker-Dealers Would Actually Go Under OLA?}

As a threshold matter, the OLA applies only in a narrow set of circumstances. First, the OLA only applies to the most systemically important broker-dealers under severely adverse financial conditions. ${ }^{103}$ Consequently, some have argued that financial firms are incentivized to become "too big to fail" in order to be covered by OLA because the they would consequently have access to cheaper funding, and because the FDIC could use government funds to keep the firm running during the resolution process. ${ }^{104}$

Second, Dodd-Frank and the jointly issued implementing regulation require certain non-bank financial companies and bank holding companies to prepare resolution plans, also known as living wills, that describe the company's resolution strategy in the event of financial distress. ${ }^{105}$ A resolution plan must demonstrate the company "could be resolved under bankruptcy without severe adverse consequences for the financial system or the U.S. economy."106 Each company's resolution plan explains the company's ownership structure, how the company plans to shield its subsidiaries from risks created by the activities of its other subsidiaries, its major counterparties, and a process for determining to whom the collateral of the company is pledged. ${ }^{107}$ Companies must update their living wills periodically, and they must address any deficiencies in their plans that are identified by the Board of Governors of

103 See 12 U.S.C. § 5383(b).

104 Aaron Klein, A Primer on Dodd-Frank's Orderly Liquidation Authority, BROOKINGS (June 5, 2017), https://www.brookings.edu/blog/upfront/2017/06/05/a-primer-on-dodd-franks-orderly-liquidation-authority [https://perma.cc/TQA4-M8TK].

105 Dodd-Frank Act $\S \S 115(d)(1), 165(d)$.

106 Bd. of Governors Fed. Reserve Sys. \& Fed Deposit Ins. Corp, Resolution Plan Assessment Framework and Firm Determinations 1 (2016), https://www.federalreserve.gov/newsevents/pressreleases/files/bcreg20160413a2.pdf [https://perma.cc/ZPD7-NUY3].

10712 C.F.R. $\S \S 243.5,381.5$ (2019) (informational content of a full resolution plan). 
the Federal Reserve System and the FDIC. ${ }^{108}$ Because they are prepared for resolution under the Bankruptcy Code, companies maintaining living wills are unlikely candidates for OLA resolution.

Third, the most systemically important broker-dealers are likely to be part of a global systemically important banking group ("G-SIB"). ${ }^{109}$ GSIBs are required to prepare resolution plans, and many have a single-point-of-entry ("SPOE") resolution strategy as their preferred strategy for resolution. ${ }^{110}$ Under SPOE the FDIC (as receiver of the top-level holding company) allows all of the holding company's subsidiaries, including its broker-dealers, to continue operating. ${ }^{111}$ For instance, a G-SIB parent would enter bankruptcy while certain legal entities would continue operating for the benefit of the parent's bankruptcy estate. As such, a broker-dealer part of a G-SIB would fall under a SPOE strategy rather than separated its affiliated entities for direct liquidation under the OLA.

Thus, the OLA may have a limited application: it applies to broker-dealers whose failure would have an adverse impact on the financial system but who are not subsidiaries of a G-

10812 U.S.C. $§ 5365(d)(4) ; 12$ C.F.R. $\$ \S 243.8(c), 381.8(c)$.

109 G-SIBs are designated by the Financial Stability Board. Global Systematically Important Financial Institutions, FIn. STABILITY BOARD https://www.fsb.org/work-of-the-fsb/policy-development/addressing-sifis/global-systemically-important-financial-institutions-g-sifis/ [https://perma.cc/G6JC-74BB] (last visited July 1, 2020). As of November 2019, there are thirty G-SIBs. See Fin. Stability BD., 2019 List OF GlobaL SYSTEMICALlY IMPORTANT BANKS (G-SIBs) 3 (2019), https://www.fsb.org/wpcontent/uploads/P221119-1.pdf [https://perma.cc/2SBY-PAJM].

110 See Resolution of Systematically Important Financial Institutions: The Single Point of Entry Strategy, 78 Fed. Reg. 76,614 (proposed Dec. 18, 2013); Paul L. Lee, A Paradigm's Progress: The Single Point of Entry in Bank Resolution Planning, CLS BLUE SKY BLOG (Jan. 18, 2017), https://clsbluesky.law.columbia.edu/2017/01/18/a-paradigms-progress-thesingle-point-of-entry-in-bank-resolution-planning/ [https:/perma.cc/H4SQ8ZGJ] (noting that regulators generally prefer a SPOE resolution strategy, and that such a strategy has been adopted by seven of the eight systemically important U.S. banking institutions).

111 See generally id. See also Klein, supra note 104. Further discussion of the SPOE strategy is beyond the scope of this Note. 
SIB and do not have maintain a living will.112 Only a small group of companies meet these requirements, although fintech firms may be among them. Cryptocurrency is one of the most immediately recognizable symbols of fintech, ${ }^{113}$ however fintech also encompasses wealth management robo-advisors, payments systems, and online brokerage platforms. ${ }^{114}$ As fintech firms become bigger players in the markets-integrating with traditional institutions, attracting more pervasive use by investors, and eating away at the separation of banks and brokerage firms - they may fit the criteria for the OLA, and may further complicate the implementation of an OLA regime already plagued with uncertainty. ${ }^{115}$

\section{CONFLICT OF CONTROL BETWEEN THE SIPC AND FDIC}

Before Dodd-Frank was passed, the SIPC, operating under SIPA, managed the liquidation of broker-dealers. ${ }^{116}$ Under Dodd-Frank's OLA, however, the FDIC obtained some

112 For example, Citigroup Global Markets Inc. ("CGMI") is a registered securities broker-dealer, SIPC-member, and a subsidiary of Citigroup, a G-SIB. See Firms We Regulate, FINRA (July 24, 2020), https://www.finra.org/about/firms-we-regulate [https://perma.cc/BS84CLE6]; List of Members, SIPC, https://www.sipc.org/list-of-members/ [https://perma.cc/R525-6UBS] (last visited July 1, 2020); FIN. STABILITY BD., supra note 109. Citigroup's most recent resolution plan sets for a SPOE resolution strategy. See Citigroup, Inc., 2019 Resolution Plan 3 (2019), https://www.federalreserve.gov/supervisionreg/resolution-plans/citigroup1g-20190701.pdf [https://perma.cc/68FZ-J39T]. Should CGMI fail, it is unlikely it would be directly liquidated under OLA without consideration of the overall resolution plan for the G-SIB.

113 Generally, the term "cryptocurrency" refers to a digital currency with "no central issuing or regulating authority." See Cryptocurrency, MERRIAM-WEBSTER, https://www.merriam-webster.com/dictionary/cryptocurrency [https://perma.cc/5HFA-MWW4] (last visited July 1, 2020).

114 See Fin. Stability BD., Financial Stability Implications From FinTech: Supervisory and Regulatory Issues that Merit Authorities' ATTENTION 7-9 (2017), https://www.fsb.org/wp-content/uploads/R270617.pdf [https://perma.cc/883G-3BMZ].

115 See infra Section IV.B.

11615 U.S.C. $\S \S 78 \mathrm{eee}(\mathrm{b})(3), 78 \mathrm{eee}(\mathrm{d})(2018)$. 
authority over such liquidations. ${ }^{117}$ Given this overlapping authority, the OLA liquidation process lacks clarity and creates conflicts of authority between the FDIC and SIPC. The Proposed Rules attempted to solve this issue, but failed to do so completely. Furthermore, given the Trump administration's deregulatory goals, ${ }^{118}$ it is unlikely that the Proposed Rules will be made final any time soon. Thus, ten years after DoddFrank was passed, with the process of resolving a failing broker-dealer remains an uncertain affair.

This ambiguity is especially troubling as the next financial crisis approaches. Economists and politicians have warned that the odds of an economic downturn this or next year are high and growing. ${ }^{119}$ The COVID-19 pandemic gives these predictions added force. ${ }^{120}$ The Chair of the Federal Reserve, Jerome Powell, has warned we are in the worst recession since

117 Dodd-Frank Act, Pub. L. No. 111-203, §§ 204(b)-(c), 124 Stat. 1376, 1455 (2010) (codified at 12 U.S.C. $\S \S 5384(b)-(c)(2018)$ ).

118 See Executive Order 13771 of January 30, 2017, Reducing Regulation and Controlling Regulatory Costs, 82 Fed. Reg. 9,339 (Feb. 3, 2017); Council of Econ. Advisers, Deregulation that Frees the Economy, White House (Feb. 21, 2018), https:/www.whitehouse.gov/articles/deregulationthat-frees-the-economy/ [https://perma.cc/DDT5-AKX8].

119 See, e.g., J.P. Morgan Has a Date for the Next Financial Crisis-and It's Not Far Off, FoRTUNE (Sept. 13, 2018), https://fortune.com/2018/09/13/jpmorgan-next-financial-crisis/ [https://perma.cc/WPF7-NTPN]; Tucker Higgins, Elizabeth Warren Says the 'Warning Lights Are Flashing' for the Next Economic Crash, CNBC (July 22, 2019), https://www.cnbc.com/2019/07/22/elizabeth-warren-warns-next-economic-crash-is-coming.html [https://perma.cc/X8C3-T9P6]; Philip Inman, Pessimists Are Predicting a Global Crash in 2020. You Can See Why, GuARDian (Jan. 5, 2019), https://www.theguardian.com/business/2019/jan/05/global-economic-crash2020-understand-why [https://perma.cc/Z97Q-G3P3].

120 See World Bank GrP., Global Economic Prospects 13 (2020), https://openknowledge.worldbank.org/bitstream/handle/10986/33748/9781464815539.pdf [perma.cc/4CGP-CHJN]. 
World War II. ${ }^{121}$ Thus, although the OLA has not yet been triggered, it may soon be put to use. ${ }^{122}$

\section{A. Difficulty of Making "Customer Property" Determinations}

As discussed above, not all investors are viewed equally under SIPA. The determining factor for SIPC coverage is whether a "customer" has a claim on "customer property." 123 SIPA protects customers by prioritizing claims for customer property over other claims. ${ }^{124}$ But who qualifies as a "customer" and what qualifies as "customer property" entitled to SIPA protection? The answer is not always clear ${ }^{125}$ While the terms are defined under SIPA, ${ }^{126}$ applying the statutory definitions to dynamic financial products has proven to be complex and has often necessitated litigation.

Consider the example of Bernie Madoff's Ponzi scheme. The failure of Madoff's brokerage firm, Bernard L. Madoff Investment Securities LLC ("BLMIS"), revealed the theft of $\$ 17$ billion of customer assets. ${ }^{127}$ Under the Bankruptcy Code and SIPA, the Madoff bankruptcy trustee has recovered approximately $\$ 14.3$ billion from Madoff's associates, feeder funds,

121 Jeanna Smialek et al., Fed Chair Warns the Economy May Need More as Congress Hesitates, N.Y. TIMEs (June 16, 2020), https://www.nytimes.com/2020/05/13/business/economy/fed-chair-powell-economy-virussupport.html [https://perma.cc/Z8W6-2H3Z].

122 Recently, the Agencies issued a final rule implementing OLA for covered brokers and dealers. See supra note 5. Agency action on the Proposed Rules after four years of inaction provides further support that OLA may soon be put to use.

123 See supra Section II.B.2.

124 SEC v. Kenneth Bove \& Co. Inc., 378 F. Supp. 697, 700 (S.D.N.Y. 1974).

125 See Joo, supra note 48, at 1121-22 (noting the "complicated jurisprudence regarding the definition of a 'customer claim"').

12615 U.S.C. $\$ 78 l l l(2)-(4)$ (2018).

127 The liquidation of Bernard L. Madoff Investment Securities LLC commenced on Thursday, December 11, 2008, in the United States District Court for the Southern District of New York. See Bernard L. Madoff Investment Securities LLC, SIPC, https://www.sipc.org/cases-and-claims/opencases/bernard-l-madoff-investment-securities-llc/ [https://perma.cc/D9APTUUG] (last visited July 1, 2020). 
and beneficiaries of the scheme, and has distributed approximately $\$ 13.9$ billion to eligible BLMIS customers, including approximately $\$ 850$ million in advances from the SIPC fund. ${ }^{128}$ The distributions amount to $69 \%$ of all allowed customer claims, and customer claims up to $\$ 1.5$ million have been fully satisfied. ${ }^{129}$

Indirect investors in BLMIS have not fared as well. The Second Circuit denied many of their claims, finding that these indirect investors did "not qualify as BLMIS 'customers' under SIPA." 130 The Second Circuit made this finding despite the fact that these investors had invested in two feeder funds that deliberately marketed themselves as providing access to BLMIS. ${ }^{131}$

As discussed above, when a broker-dealer's assets are insufficient to compensate customers for their losses, each customer can have its remaining losses covered by the SIPC, up to $\$ 500,000$ per customer. ${ }^{132}$ Accordingly, many of BLMIS' indirect investors filed claims in its SIPA liquidation proceeding. ${ }^{133}$. However, the SIPA trustee denied their claims on the basis that the indirect investors were not "customers" of

128 Madoff Trustee Requests Allocation of More Than $\$ 988$ Million to Customer Fund and Court Approval to Distribute More Than \$332 Million to BLMIS Customers with Allowed Claims, SIPC (Dec. 18, 2019), https://www.sipc.org/news-and-media/news-releases/20191218-2 [https://perma.cc/37CM-UPR3]; Recoveries to Date, MADOFF RECOVERY INITIATIVE, https://www.madofftrustee.com/recoveries-25.html [https://perma.cc/J6CB-CE49] (last visited July 1, 2020).

129 Press Release, Irving H. Picard, Statement Regarding Bankruptcy Court Approval of Eleventh Pro Rata Interim Distribution (Jan. 8, 2020), https://www.madofftrustee.com/document/news/000985-eleventh-allocation-court-approval-statement-10820-final.pdf [https://perma.cc/6MFY8DMS].

130 See In re Bernard L. Madoff Inv. Secs. LLC, 708 F.3d 422, 427 (2d Cir. 2013).

131 See id. at 425. The two funds were Spectrum Select, L.P. and Spectrum Select II, L.P. Id.

132 See supra notes 59-62 and accompanying text.

133 See Brief of the Appellants, In re Bernard L. Madoff Inv. Secs. LLC, 708 F.3d 422 (2d. Cir. 2013) (No. 12-483), 2012 WL 1898954. 
BLMIS per SIPA. ${ }^{134}$ The Bankruptcy Court, District Court, and Second Circuit agreed with the trustee that only the feeder funds themselves-which had invested with BLMIS through securities accounts in their names-were "customers" of BLMIS. ${ }^{135}$ As a result, only the feeder funds were entitled to up to $\$ 500,000$ in uncompensated losses from SIPC, and the indirect investors, as non-customers, were only "eligible to recover a fraction of that amount," indirectly through the feeder funds. ${ }^{136}$ Thus, the recovery of the investors hinged on whether they were "customers" under SIPA. In ruling that the indirect investors were not customers, the courts highlighted the narrow definition of "customer" under SIPA, and the importance of customer status determinations to SIPC protections. ${ }^{137}$

The treatment of repurchase agreement transactions ("repos") under SIPA further illustrates the importance and difficulty of the "customer" and "customer property" determinations. A repo occurs in two steps: first, the seller agrees to sell assets, typically securities, to the buyer for a fixed price, and second, the buyer agrees to resell those same assets back to the seller at a later date and for a slightly higher price. ${ }^{138}$ If one of the parties should enter a SIPA liquidation prior to the conclusion of the second step, it may not be so obvious if the

134 In re Bernard L. Madoff Inv. Secs. LLC, 454 B.R. 285, 289-90 (Bankr. S.D.N.Y. 2011).

135 See id. The Second Circuit affirmed the decisions of the District Court and Bankruptcy Court that the investors in the feeder funds were not "customers" of BLMIS entitled to SIPA protection. See In re Bernard L. Madoff Inv. Secs., 708 F.3d. at 422.

136 Id. See also Rahul Sharma, Second Circuit Rules that SIPA Customer Protections Are for Customers Only, WeIL, Gotshal \& MANGEs LLP BANKR. BLOG (Mar. 25, 2013), https://business-finance-restructuring.weil.com/sipa-proceedings/second-circuit-rules-that-sipa-customer-protections-are-for-customers-only/ [https://perma.cc/YA5F-9U6F].

137 In re Bernard L. Madoff Inv. Secs., 454 B.R. at 294; In re Bernard L. Madoff Inv. Secs., 708 F.3d. at 426.

138 See Shmuel Vasser, Where Repo And 'Customer' Claims Differ Under SIPA, LAw360 (July 10, 2013), https://www.law360.com/articles/456341/where-repo-and-customer-claims-differ-under-sipa [https://perma.cc/RPS2-BZZR]. 
counterparty should be treated as a "customer" of the failing party for SIPA purposes.

In Bevill, Bresler, the New Jersey District Court determined that, under a literal reading of the SIPA definition, a repo seller qualify as a "customer" of the broker-dealerbuyer. ${ }^{139}$ Between the two steps of the repo transaction, a repo seller has a claim for the securities held by the broker-dealer, the securities were received from the securities account of the claimant, and the securities are held by the broker-dealer pursuant to the (re)purchase of the securities by the seller. ${ }^{140}$ The District Court did note that merely satisfying the literal requirements of SIPA might not be enough considering courts have generally taken a restrictive view of "customer" and require that (i) the claim of customer status must be related to investment, trading or participation in the securities market, and (ii) the transaction must arise out of a fiduciary or entrustment relationship. ${ }^{141}$ Yet the court cursorily concluded the requirements were present and extended customer status to repo participants, rejecting SIPC's contention that a customer must be trading through rather than with the bankrupt broker-dealer as a "gross oversimplification." 142

The repo issue was addressed again in the Lehman Brothers ("Lehman") liquidation under SIPA. ${ }^{143}$ In the Lehman case, the Second Circuit explicitly rejected Bevill, Bresler as inconsistent with case law and failing to demonstrate how repo parties entrust assets to broker-dealers, ${ }^{144}$ and determined that the claimants, parties to stock repos with Lehman, were not customers entitled to recovery under SIPA. ${ }^{145}$

139 In re Bevill, Bresler \& Schulman Asset Mgmt. Corp., 67 B.R. 557, 599 (D.N.J. 1986).

140 See id.; 15 U.S.C. $§ 78 l l l(2)$ (2018).

141 In re Bevill, 67 B.R. 557 at 600.

142 Id. at 600-01.

143 In re Lehman Bros., Inc., 791 F.3d 277, 280 (2d Cir. 2015).

144 Id. at 288-89 ("In short, although Bevill, Bresler acknowledges Baroff and our other entrustment precedents, the decision does not actually demonstrate how repo parties entrust assets to failed broker-dealers. Accordingly, we find Bevill, Bresler to be inconsistent with our caselaw, and decline to follow it here.").

145 See id. at 279. 
Lehman, the buyer in a repo transaction, failed prior to the repurchase date, and the underlying securities appreciated such that the seller stood to profit if it repurchased the securities at the agreed-upon price. ${ }^{146}$ After Lehman entered into SIPA liquidation, Doral submitted claims asserting it was entitled to recover its profit. The Second Circuit affirmed the SIPA trustee's denial of the claims, concluding the seller was not a "customer" of Lehman with respect to the repo. ${ }^{147}$ The Court highlighted that a customer must have "entrusted" property to the broker-dealer for use on her behalf. ${ }^{148}$ Entrustment must bear the "indicia of a fiduciary relationship," which arises out of the broker-dealer's obligation to handle the customer's assets for the customer's benefit. ${ }^{149}$ As Lehman had full legal title over the underlying securities, subject only to its obligation to resell the securities on the repurchase date, it had power to dispose of the securities as it saw fit as was not entrusted with the securities. ${ }^{150}$ As such, the seller was not a customer entitled to SIPA protection. ${ }^{151}$

The foregoing examples highlight the importance of customer status and customer property determinations, reflect the SIPC's experience with making such decisions, and outline the judicial precedents on point. The SIPC's track record, coupled with past court decisions on the matter gives investorsparticularly customers - a considerable degree of certainty as to whether SIPA will protect their investments. But when it comes to OLA, by contrast, investor certainty is threatened.

\section{B. Overlapping Authority of the SIPC and FDIC under OLA}

When Dodd-Frank was enacted, it was generally understood that, under the OLA, the SIPC's authority over brokerdealers was split with the FDIC. The OLA states that the

\footnotetext{
$146 I d$. at 280.

$147 \mathrm{Id}$.

$148 I d$. at 283.

149 Id. at 283 .

150 See id. at 283, 286.

151 Id. at 289.
} 
FDIC, upon its appointment as receiver for a covered brokerdealer, "shall appoint, without any need for court approval, the [SIPC] to act as trustee for the liquidation under [SIPA] of the covered broker or dealer." 152 Further, the OLA provides "an application for a protective decree under [SIPA] as to the covered broker or dealer," 153 and states that "the determination of claims and the liquidation of assets . . shall be administered under [SIPA] by [the] SIPC." 154 The SIPC is obligated to dispense with customer claims on the same basis as SIPA. ${ }^{155}$ Thus, one could fairly read the OLA's language to mean that a liquidation will be performed by the SIPC under SIPA, with the FDIC involved as receiver.

But how do the FDIC and SIPC share authority? The statutory language is unclear as to what exactly the split of authority entails. That is, the OLA grants the SIPC all the powers and duties it has under SIPA, and requires the SIPC to conduct the liquidation of broker-dealers in accordance with SIPA. ${ }^{156}$ The OLA further states that the SIPC must determine and satisfy, consistent with the OLA and SIPA, all claims against broker-dealers that arose on or before their filing date. ${ }^{157}$ At the same time, the SIPC "shall not impair or impede the exercise of the powers and duties of the [FDIC]" in making funds available for the receiver, transferring assets and liabilities to bridge financial companies, and determining claims against the FDIC as receiver. ${ }^{158}$ Moreover, the OLA also makes clear that the SIPC shall have no powers or duties with respect to the assets transferred by the FDIC from broker-dealers to bridge financial companies. ${ }^{159}$ Consequently, the SIPC only has power to determine claims and liquidate assets retained in the receivership of broker-dealers; once assets are transferred to a bridge financial company, they are

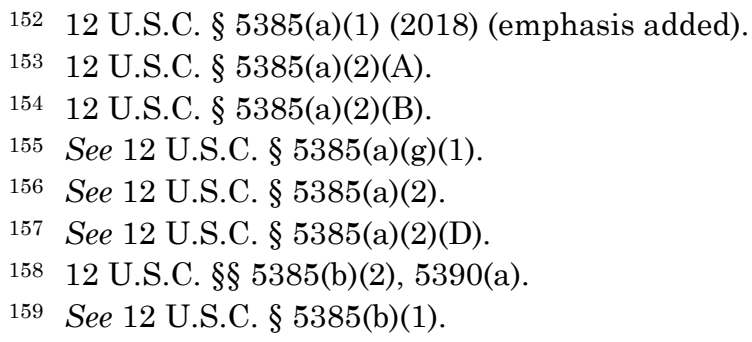


outside the scope of the SIPC's authority. ${ }^{160}$ Thus, although the SIPC seems to have full authority to make determinations on claims under SIPA, the OLA allows the FDIC to take actions that may inhibit claims from being fulfilled.

To further complicate the matter, the OLA requires the FDIC to consult with the SIPC to determine whether customer accounts ought to be transferred from a broker-dealer to a bridge financial company, ${ }^{161}$ and prohibits the FDIC from making transfers that impair recoveries provided to customers under SIPA, or those that otherwise adversely affect the rights of customers to customer property. ${ }^{162}$ Even within the legal community, there was no clear agreement on the roles the FDIC and SIPC would play. One law firm, for example, advised that the FDIC should play a limited role and the SIPC should continue to be largely responsible for proceedings conducted under the OLA, ${ }^{163}$ while another stated that the liquidation proceedings generally would be governed by SIPA, but that the FDIC would act under the OLA, not SIPA. ${ }^{164}$ And who determines customer claims? From the statutory language, it seems the answer is both the SIPC and the FDIC together, with SIPA rules governing, unless otherwise specified by OLA. But this answer is less than satisfactory.

While the OLA appears to contemplate that the FDIC will commence a liquidation under it, it also appears to mandate that the SIPC conduct a liquidation under SIPA. ${ }^{165}$ This lack

160 See 12 U.S.C. $\S 5385(\mathrm{a})(2)(\mathrm{B})$.

161 See 12 U.S.C. $\$ 5384(\mathrm{c})(4)$.

162 See 12 U.S.C. $§ 5385(d)(1)$.

163 See Donald S. Bernstein et Al., Davis Polk, A Creditor's Guide TO THE FDIC's ORDERLY LIQUIDATION AUTHORITY 8 (2011), https://www.davispolk.com/files/uploads/OLA.Presentation.11.30.11.pdf [https://perma.cc/8J65-RKUD].

164 See Mark C. Ellenberg et Al., CAdWAlader, Orderly Liquidation of Financial Companies, Including Executive Compensation Clawback, Under the Dodd-Frank Wall Street Reform And Consumer Protection ACT $\quad 3 \quad$ (2010), https://www.cadwalader.com/uploads/cfmemos/9c921bed3e5fdcdf29c014c413740f29.pdf [https://perma.cc/J24Z-VPRN].

165 See Dodd-Frank Act, Pub. L. No. 111-203, §§ 204(b)-(c), 205(a)-(b), 124 Stat. 1376, 1455 (2010) (codified at 12 U.S.C. $§ 5384$ (2018)). See also Lubben, supra note 32 . 
of clarity has led to widespread confusion over Dodd-Frank's treatment of failed broker-dealers. Acknowledging the confusion, the FDIC and the SEC (collectively, "the Agencies") responded by issuing the Proposed Rules. ${ }^{166}$

\section{Ambiguity of the Proposed Rules Implementing OLA}

In an attempt to find a path out of the muddy OLA waters, the Agencies issued the Proposed Rules to implement the OLA's broker-dealer provisions. ${ }^{167}$ These rules sought to clarify "[h]ow the customer protections of SIPA will be integrated with the other provisions of [the OLA]; the roles of the [FDIC] as receiver and SIPC as trustee for a covered broker-dealer; and the administration of claims in an orderly liquidation of a covered broker-dealer." 168 However, upon close examination, the Proposed Rules remain problematic for broker-dealer customers. Specifically, the language of the Proposed Rules does not eliminate the crucial ambiguity surrounding the authority of the FDIC and SIPC: which body has the authority to make the final determination on what is to be treated as customer property?

Consistent with the statutory directive of Dodd-Frank, 169 the Proposed Rules mandate that customers be "treated in a manner at least as beneficial as would have been the case had the broker-dealer been liquidated under SIPA." 170 At the same time, the Proposed Rules state that "in reality there is no proceeding under SIPA and the covered broker-dealer is being liquidated under [the OLA]."171 Additionally, the discretion

166 See Covered Broker-Dealer Provisions Under Title II of the DoddFrank Wall Street Reform and Consumer Protection Act, 81 Fed. Reg. 10,798 (proposed Mar. 2, 2016) (to be codified at 12 C.F.R. pt. 380 and 17 C.F.R. pt. 302). The rules as proposed are promulgated pursuant to DoddFrank section 205(h), which requires the SEC and FDIC, in consultation with SIPC, to jointly issue rules concerning the orderly liquidation of covered broker-dealers. See Dodd-Frank Act § 205(h).

167 See 81 Fed. Reg. at 10,798.

$168 I d$. at 10,800 .

169 See Dodd-Frank Act $§ 205(f)(1)$.

17081 Fed. Reg. at 10,803.

171 Id. at 10,801 . 
given to the FDIC to determine customer status and customer property, in light of the conflicting and ambiguous language of the Proposed Rules, creates doubt that customers will enjoy the full protections provided by SIPA.

\section{Who Determines "Customer Property"?}

In the spirit of SIPA, the Proposed Rules state that the "SIPC, as trustee for a covered broker or dealer, shall determine customer status, claims for net equity, claims for customer name securities, and whether property of the covered broker or dealer qualifies as customer property."172 The SIPC is to make claim determinations in accordance with SIPA. ${ }^{173}$ However, although the SIPC is tasked with making customerrelated determinations, "such determinations, and any claims related thereto, shall be governed by the procedures set forth in [the Proposed Rules]."174

The receiver's role in determining claims against the FDIC is specified in the next subsection of the Proposed Rules. ${ }^{175}$ In addition to setting notice requirements and procedures and deadlines for filing a claim, the relevant subsection addresses customer claims. ${ }^{176}$ There are three key portions to the subsection: First, the FDIC, as receiver, "shall notify a claimant whether it allows or disallows the claim, or any portion of a claim or any claim of a security, preference, set-off, or priority" within a specified time period.177 Second, in issuing the required notice of decision on customer claims, the FDIC "shall utilize the determination made by [the] SIPC . . . in a manner consistent with [the] SIPC's customary practices in a liquidation under SIPA, with respect to any claim for net equity or customer name securities."178 Third, the process established in the section detailing the determination of claims for customer property and customer name securities "shall

172 Id. at 10,815

173 See id.

174 Id.

175 See id. at 10,815-16.

176 See id. at 10,816.

$177 I d$. (emphasis added).

$178 I d$. (emphasis added). 
constitute the exclusive process for the determination of such claims," and any procedures for expedited relief under the OLA are "inapplicable to such claims."179

The above portions of the Proposed Rules are troubling. Despite the stated responsibility of the SIPC to make determinations on customer status and customer property in accordance with SIPA, the FDIC has the ability to allow or disallow claims on any portions thereof. ${ }^{180}$ Although the FDIC, in making its decision to allow or disallow a claim , is to "utilize" the SIPC determinations, ${ }^{181}$ it need not defer to the SIPC. In short, the Proposed Rules leave the FDIC to make the final determination on customer claims, including whether such claims pertain to "customer property" as defined under SIPA and as interpreted by federal courts over almost fifty years. In effect, even if the SIPC makes a determination that a customer claim is a claim for allowed customer property, the FDIC's ability to allow or disallow a claim gives it the power to make its own determinations that diverge from those of the SIPC.

A filing for an OLA proceeding dismisses any existing case or proceeding under the Bankruptcy Code or SIPA, ${ }^{182}$ and may also allow for the "revesting of assets" in a covered brokerdealer if the assets have been vested in any other entity as a result of a proceeding already commenced under SIPA. ${ }^{183}$ Presumably, such dismissed proceedings would include proceedings where customer assets have already been determined by the SIPC and are in the process of being transferred to another broker-dealer under SIPA. Squaring this priority of OLA proceedings with the ultimate purpose of the OLA requires that the FDIC have control of the proceedings,

179 Id. (emphasis added). See also 12 U.S.C. § 5390(a)(5) (2018) (outlining the process for the expedited determination of claims that are inapplicable to claims for customer property or customer name securities under the Proposed Rules).

180 See 81 Fed. Reg. at 10,798, 10,815-16, 10,818-19.

181 Id. at 10,816 .

182 See 12 U.S.C. $\S 5388(a)$.

183 See 12 U.S.C. $§ 5388(b)$. 
including the ability to override SIPC determinations, with respect to customer property determinations and otherwise.

Finally, the portion of the Proposed Rules that pertains to claims of customers stipulates that a claimant "may seek a judicial determination of any claim disallowed, in whole or in part, by the [FDIC] as receiver, including any claim disallowed based upon any determination(s) of [the] SIPC as trustee made pursuant to [the Proposed Rules]."184 That the FDIC's determinations on claims are based upon SIPC determinations reinforces the notion that SIPC determinations are merely recommendations that the FDIC has no obligation to follow. If the FDIC were obligated to follow the determinations of the SIPC, it would be unnecessary to note that FDIC determinations are "based" on the determinations of the SIPC. Thus, the Proposed Rules pertaining to judicial review of decisions on customer claims takes for granted that FDIC determinations may diverge from original SIPC determinations on customer property. That determination is crucial because what constitutes customer property affects all other calculations, including the amount of non-customer property left available. ${ }^{185}$

At best, considering the stated goal of the Proposed Rules to leave broker-dealer customers no worse off under the OLA than under SIPA, the FDIC's broad power to effectively override the SIPC's determinations may be unintended. However, at the very least, the language of the Proposed Rules produces ambiguity regarding who determines claims, and therefore decreases investor confidence as to what exactly will constitute customer assets following the failure of a covered brokerdealer. As discussed above, determinations as to what qualifies as a claim on customer property are contentious and not always clear. ${ }^{186}$ The language granting the FDIC the power to make final determinations raises litigation risks and undermines customer confidence in SIPA protections. At worst, the Proposed Rules leave the door open for arbitrary determinations by the FDIC. In relying on the OLA's goal to protect the

18481 Fed. Reg. at 10,816, 10,819 (emphasis added) (citations omitted).

185 See supra notes 46-65 and accompanying text.

186 See supra notes 69-73, 123-151 and accompanying text. 
stability of the financial economy and the FDIC's mission to protect customers of commercial banks, the FDIC may overrule SIPC determinations for the sake of political or territorial expediency.

Although they tried, the Proposed Rules have not solved the confusion regarding whether the FDIC or SIPC makes customer property determinations, leaving the OLA just as perplexing as before. The OLA's ambiguity was compounded by the Trump presidency, which called into question not only the Proposed Rules, but also the OLA's existence itself. DoddFrank was a Democratic bill passed with just three Republican votes in the House and three Republican votes in the Senate $^{187}$ and has been under attack from Republicans ever since. ${ }^{188}$ The Proposed Rules were issued when Obama-appointed Chairmen led the FDIC and SEC. ${ }^{189}$

In 2016, the SEC and FDIC listed the Proposed Rules on the Fall 2016 release of the Unified Agenda of Federal Regulatory and Deregulatory Actions (the "Agenda") as being in the "Final Rule Stage," with final action expected sometime in

187 See H.R. 4173 (111th): Dodd-Frank Wall Street Reform and Consumer Protection Act, GovTRACK (July 15, 2010), https://www.govtrack.us/congress/votes/111-2010/s208 [https://perma.cc/W2WJ-PMH2].

188 See, e.g., Alan Rappeport \& Emily Flitter, Congress Approves First Big Dodd-Frank Rollback, N.Y. Times (May 22, 2018), https://www.nytimes.com/2018/05/22/business/congress-passes-dodd-frank-rollback-forsmaller-banks.html [https://perma.cc/7JSN-8UDG].

189 Obama-appointed Martin J. Gruenberg served as Chairman of the FDIC from November 15, 2012 until Trump-appointed Jelena McWilliams was sworn in on June 5, 2018. See List of Chairmen of the FDIC, FDIC (Aug. 23, 2018), https://www.fdic.gov/about/history/chairmen.html [https://perma.cc/75W9-M8QS]. Obama-appointed Mary Jo White served as Chair of the SEC from April 10, 2013 until January 20, 2017. See Biography of Mary Jo White, U.S SEC. \& Exchange Commission, https://www.sec.gov/biography/white-mary-jo [https://perma.cc/7Y9YMHDV] (last visited July 1, 2020). Trump-appointed Jay Clayton was sworn in as Chair of the SEC on May 4, 2017. See SEC Historical Summary of Chairmen and Commissioners, U.S. SEC. \& ExChange CoMmission (May 4, 2017), https://www.sec.gov/about/sechistoricalsummary.htm [https://perma.cc/5CQE-EW8J]. 
November 2016. ${ }^{190}$ In January 2017, the Trump presidency began. ${ }^{191}$ As President Trump had promised to enact deregulatory measures across federal agencies if he were elected president, ${ }^{192}$ it came as no surprise that the Proposed Rules were one of twenty-two actions re-classified as "long-term actions" in the administration's first released Agenda. ${ }^{193}$ However, along with the deregulatory moves across the federal agencies, the Trump Administration also drafted a threat to the OLA itself.

\section{Treasury Report on OLA and the Current Status of Reform}

In April 2017, President Trump issued a presidential memorandum instructing the U.S. Department of the Treasury to undertake a review of the OLA and to consider whether adding a new chapter to the Bankruptcy Code would better resolve a failing financial firm. ${ }^{194}$ The Memorandum directed the Treasury to consider the OLA's cost to the Treasury, its effect on risk taking by market participants, and its relationship to taxpayer-funded bailouts. ${ }^{195}$ Some read the memorandum as indicating that the Trump administration intended to

190 See OfFice of Info. \& Reg. AfFairs, Fall 2016 Regulatory Plan AND UNIFIED AGENDA (2016).

191 See Peter Baker \& Michael D. Shear, Donald Trump Is Sworn in as President, Capping His Swift Ascent, N.Y. Times (Jan. 20, 2017), https://www.nytimes.com/2017/01/20/us/politics/trump-inaugurationday.html [https://perma.cc/2Z5Y-JLEC].

192 Maeve P. Carey \& Kathryn A. Francis, Cong. Research Serv., R45032, The Trump Administration And the Unified Agenda of Federal REGUlATORY AND DEREgUlatory ACTIONS 1 (2017).

193 See Office of Info. \& Reg. AfFairs, Spring 2016 Unified AgEndA OF FEDERAL REgUlatory AND DEREGUlatory ACTIONS (2016).

194 Memorandum on Orderly Liquidation Authority, 2017 DAILY COMP. PRES. Doc. 266, at 1-2 (Apr. 21, 2017).

195 See id. See also Randall D. Guynn et al., The Presidential Memorandum on the Orderly Liquidation Authority-Another Look, DAVIS POLK\& WARDWELL: FINREG (Apr. 25, 2017), https://www.finregreform.com/singlepost/2017/04/25/the-presidential-memorandum-on-the-orderly-liquidationauthority-another-look/ [https://perma.cc/NK4H-NWP5]. 
repeal the OLA. ${ }^{196}$ Around that time the OLA remained controversial, especially after the Financial CHOICE Act of 2017, a Republican proposal that would repeal the OLA, passed the Republican-led House almost entirely along party lines in June 2017. ${ }^{197}$ For a while, it seemed that a key post-financial crisis reform was at risk of being undone.

However, the OLA's fate changed for the better when the Treasury, in its long-awaited report, recommended reforming-but not repealing - the OLA. ${ }^{198}$ While the Treasury recommended a new Chapter 14 of the Bankruptcy Code be established to address distressed financial companies, 199 it simultaneously proposed retaining the OLA, albeit with certain reforms "to eliminate opportunities for ad hoc disparate treatment of similarly situated creditors, reinforce existing taxpayer protections, and strengthen judicial review." 200 While observing "serious defects" in the OLA, the Treasury Report argued that a reformed OLA should include a "predictable and clear allocation of losses." 201 This followed from the core principle of its recommendations that "a sound resolution

196 See, e.g., Lalita Clozel, Trump Invites Trouble in Targeting FDIC Resolution Powers, AM. BANKER (Apr. 21, 2017), https://www.americanbanker.com/news/trump-invites-trouble-in-targeting-fdic-resolution-powers [https://perma.cc/TM68-SN7W].

197 See, e.g., Ben S. Bernanke, Why Dodd-Frank's Orderly Liquidation Authority Should Be Preserved, BRookIngs (Feb. 28, 2017), https://www.brookings.edu/blog/ben-bernanke/2017/02/28/why-dodd-

franks-orderly-liquidation-authority-should-be-preserved/

[https://perma.cc/TM8S-Y6YG] (noting that "controversies remain over how effective even a Title II resolution would be in the context of a significant financial crisis"); Paul L. Lee, The Case Against Repealing Title II of the Dodd-Frank Act, CLS BLUE SKY BLOG (Dec. 12, 2016), https://clsbluesky.law.columbia.edu/2016/12/12/the-case-against-repealingtitle-ii-of-the-dodd-frank-act/ [https://perma.cc/Q86H-L5N4] ("Title II was controversial at the time of its enactment and remains controversial today.”).

198 U.S. DEP'T OF TREASURY, supra note 29, at 31.

199 Id. at 2-3.

200 Press Release, U.S. Dep't of the Treasury, Treasury Releases Report to the President on Orderly Liquidation Authority (Feb. 21, 2018), https://home.treasury.gov/index.php/news/press-release/sm0295

[https://perma.cc/XWA7-GBGT].

201 U.S. DEP'T OF TREASURY, supra note 29, at 2. 
regime should avoid moral hazard arising from the belief that certain classes of equity or debt" would be bailed out. ${ }^{202}$ In order to accomplish this, rules and procedures must be "clearly specified in advance" with a "clear, predictable hierarchy of claims." 203 Consistent with its emphasis on predictability, the Treasury Report also raised concerns that the FDIC retains too much discretion under the OLA

While it makes no mention of SIPA or the SIPC, the Treasury Report's arguments as to the need for clear, impartial rules and the clarification of standards within the OLA are applicable to the question of who gets to determine customer property. The Treasury Report reflects the shortcomings of the Proposed Rules and highlights the need for further action to clarify the ambiguous authority between the Agencies under the OLA. With a current Democratic House majority 204 and the Treasury Report's recommendation to retain the OLA, ${ }^{205}$ calls to repeal the OLA have largely subsided. ${ }^{206}$ The status of the Proposed Rules is less clear. Despite the OLA's "serious defects,"207 no statutory reform has yet succeeded, and the Proposed Rules, which appeared on the Unified Agenda of Federal Regulatory and Deregulatory Actions as recently as Fall 2019, remain caught in a regulatory lull. ${ }^{208}$ Proposals to add a new section of the Bankruptcy Code also remain on the table, but in an election year, bankruptcy reform,

$202 I d$. at 24.

203 Id. at 24, 31.

204 See Zach Montellaro, Democrats Take Back the House, PoLITICO (Nov. 7, 2018), https://www.politico.com/newsletters/morningscore/2018/11/07/democrats-take-back-the-house-404177

[https://perma.cc/X9NM-PRMR].

205 U.S. DEP'T OF TREASURY, supra note 29, at 2.

206 See Sylvan Lane, Overnight Finance: Treasury Seeks Changes to Dodd-Frank Plan on Failing Banks, HiLl (Feb. 21, 2018), https://thehill.com/policy/finance/overnights/374977-overnight-financehow-treasury-came-down-on-ola-white-house [https://perma.cc/6DSUV59V] ("The bipartisan Senate bill to loosen parts of Dodd-Frank doesn't touch OLA, and changes to the process would likely be blocked by Senate Democrats.”).

207 U.S. DEP'T OF TREASURY, supra note 29, at 2.

208 See OfFice of InFo. \& REg. AfFairs, FALL 2019 Unified AgENDA of Regulatory and Deregulatory Actions (2019). 
like OLA reform, may be less likely. ${ }^{209}$ Without reform and without the Proposed Rules, the problem the rules sought to solve persists: an unclear allocation of authority between the SIPC and FDIC. Quick resolution of this problem will be necessary if the next financial crisis occurs as soon as some expect. $^{210}$

\section{RESOLVING THE CONFLICT OF CONTROL BETWEEN FDIC AND SIPC}

No firm has undergone OLA liquidation yet, so no case law has yet been developed to assess the FDIC's use of its power as a receiver. ${ }^{211}$ It remains to be seen whether the OLA will work as designed or if the Proposed Rules offer a clear path. But the OLA can only be invoked if a financial institution fails in a manner that would have serious adverse effects on the U.S. economic system. ${ }^{212}$ Unfortunately, this means that only a severe financial downturn would trigger the OLA, and that the OLA will be tested for the first time during the next financial crisis, which may be soon.

\section{A. The Looming Financial Crisis and the Need for Certainty}

Even before the COVID-19 pandemic, some commentators predicted that the next economic downturn would arrive soon, with strategists at J.P. Morgan advising investors to pencil it in for 2020 based on an original model the firm developed. ${ }^{213}$

209 See, e.g., Rebecca Shabad, What to Expect from Congress in 2020, NBC NEWs (Jan. 6, 2020), https://www.nbcnews.com/politics/congress/whatexpect-congress-2020-n1106366 [https://perma.cc/Q97T-95MQ] ("As is typical in an election year, the House and the Senate are scheduled to be in Washington less than in off-years, spending more time campaigning in their districts.").

210 See, e.g., J.P. Morgan Has a Date for the Next Financial Crisis-and It's Not Far Off, supra note 119.

211 See Klein, supra note 104.

212 See supra notes 81-87 and accompanying text.

213 See, e.g., J.P. Morgan Has a Date for the Next Financial Crisis-and It's Not Far Off, supra note 119; Joe Weisenthal, Warnings Keep Coming About a Downturn That Will Hit in 2020, BLOOMBERG (Sept. 13, 2018), 
Some economists predict that a sharp downturn will almost certainly occur by $2021,{ }^{214}$ with many others warning that a recession is just around the corner. ${ }^{215}$ Recently, in a move to offset the impact of COVID-19 on the U.S. economy, the Federal Reserve cut its benchmark interest rate to near zero. ${ }^{216}$ This came less than two weeks after it had cut the rate by fifty basis points, ${ }^{217}$ the largest cut since October 2008, when Lehman failed and the government bailed out AIG. ${ }^{218}$ The reaction of the markets to this rate cut suggested that it gave investors a "whiff of the dark days" and signaled the extent of the economic damage the Federal Reserve anticipated would follow the pandemic. ${ }^{219}$ Commenting on the impact of COVID19 on the economy, the World Bank has warned that the

https://www.bloomberg.com/news/articles/2018-09-13/warnings-keep-coming-about-a-downturn-that-will-hit-in-2020 [https://perma.cc/83AZ-M63T].

214 See Kurt Cagle, Preparing For The Next Recession, Forbes (Oct. 2, 2019), https:/www.forbes.com/sites/cognitiveworld/2019/10/02/preparingfor-the-next-recession/\#405899df35b9 [https://perma.cc/5YPW-4YT4] ("[T]he likelihood of a sharp downturn in economic activity increases dramatically the further you get into 2020, and is near certain by 2021Q1.”).

215 See, e.g., Reade Pickert et al., U.S. Recession a Coin Toss as Chances Climb to 53\% Within Year, BloOMBERG (Mar. 10, 2020), https://www.bloomberg.com/graphics/us-economic-recession-tracker/?sref $=6 \mathrm{R} 4 \mathrm{YCukF}$ [https://perma.cc/N9VS-T8K7]; John A. Tures, When Will the Next Recession Hit and How Bad Will It Get?, OBSERVER (Sept. 28, 2019), https://observer.com/2019/09/next-recession-when-how-bad/ [https://perma.cc/CE3Z$\mathrm{XV} 4 \mathrm{U}]$.

216 Press Release, Fed. Reserve, Federal Reserve Issues FOMC Statement (Mar. 15, 2020), https://www.federalreserve.gov/newsevents/pressreleases/monetary20200315a.htm [https://perma.cc/Z6N5-R6Q9].

217 Press Release, Fed. Reserve, Federal Reserve Issues FOMC Statement (Mar. 3, 2020), https://www.federalreserve.gov/newsevents/pressreleases/monetary20200303a.htm [https://perma.cc/AV75-7HF3].

218 See Kimberly Amadeo, Fed Funds Rate History with Its Highs, Lows, and Charts, BALANCE (Mar. 3, 2020), https://www.thebalance.com/fed-funds-rate-history-highs-lows-3306135\#fed-funds-ratehistory [https://perma.cc/L262-CEEG].

219 See Editorial Board, Fed Rate Cut Is No Cure-all for Coronavirus Woes, Fin. Times (Mar. 3, 2020), https://www.ft.com/content/f46c6d0c-5d6311ea-8033-fa40a0d65a98 [https://perma.cc/FP97-ULD6]. 
pandemic represents the largest economic shock the world economy has witnessed in decades. ${ }^{220}$

Faced with a looming crisis, the federal government must take measures to prevent firms from failing and to mitigate the losses from those that do fail. In 2018, William White, the Chairman of the OECD's Economic and Development Review Committee, stated that in preparing for the next financial crisis, "[p]erhaps most important is the need for governments and international forums to revisit bankruptcy procedures." 221 White noted that the OECD's work indicates that current bankruptcy procedures in the U.S. are inadequate and have specifically failed to improve in dealing with entities that are failing and yet "too big to fail." 222 Even before the recent rate cut, early warnings prompted many law firms to begin building up their restructuring and reorganization practices over the last few years. ${ }^{223}$ But the OLA is not ready to deal with a failing broker-dealer.

As the Treasury Report noted, "[t]he success of bankruptcy for a failing financial corporation depends critically on clear rules-defined ex ante-providing for the allocation of losses." ${ }^{224}$ Although the Proposed Rules are in limbo, they are the government's last word on a broker-dealer liquidation under the OLA. Neither the OLA nor the Proposed Rules provide clear, ex ante rules regarding who should make final determinations on customer claims and whether broker-dealer customers will continue to receive SIPA protections in an OLA liquidation. As we witness echoes of the financial crisis ${ }^{225}$

220 See WorLD BANK GRP., supra note 120, at 3.

221 William White, Start Preparing for the Next Financial Crisis Now, Fin. Times (Feb. 18, 2018), https://www.ft.com/content/e1dc1286-0ccb-11e8bacb-2958fde95e5e [https://perma.cc/6KE6-HTND].

222 See id.

223 Samantha Stokes, 'It's Coming': Looming Recession Keeps Bankruptcy Partners on the Move, AM. LAW. (Oct. 29, 2019), https://www.law.com/americanlawyer/2019/10/29/its-coming-looming-recession-keeps-bankruptcy-partners-on-the-move/?slreturn=20200204131430 [https://perma.cc/4VD7-94TY].

224 U.S. DEP'T OF TREASURY, supra note 29, at 26.

225 See Michael Hiltzik, What We Learned from the Financial Crisisand What We've Already Forgotten, L.A. Times (Sept. 6, 2018), 
amidst glimmers of imprudent deregulation, ${ }^{226}$ it is thus all the more important to take action on OLA reform.

\section{Avoiding Runs on Broker-Dealers}

Why is certainty so important? As the Treasury Report stated,

a sound resolution regime should avoid moral hazard arising from the belief that certain classes of equity or debt will likely be 'bailed out' or otherwise granted special relief. That belief may arise where rules and procedures for resolution of failed financial companies are not clearly specified in advance. ${ }^{227}$

The FDIC itself acknowledges the value of certainty. In its report on how Lehman could have been resolved under the OLA (had Dodd-Frank been enacted prior to Lehman's failure), the FDIC noted that the panic and loss of confidence that Lehman's counterparties exhibited was key in precipitating Lehman's failure. ${ }^{228}$ Further, the FDIC reiterated the importance of "maintain[ing] stability and confidence in the nation's banking system," such that resolution of a failing financial company would minimize disruption to the banking system. ${ }^{229}$ Concluding that the OLA is the appropriate tool to mitigate and prevent such disruption, the FDIC highlighted the importance of clarity and certainty regarding resolution rules, noting that "[t]he very availability of a comprehensive resolution system that sets forth in advance the rules under which the government will act following the appointment of a

https://www.latimes.com/business/hiltzik/la-fi-hiltzik-fin-crisis-20180907story.html [https://perma.cc/P6BH-395D].

226 See Ben Protess \& Julie Hirschfeld Davis, Trump Moves to Roll Back Obama-Era Financial Regulations, N.Y. Times (Feb. 3, 2017), https://www.nytimes.com/2017/02/03/business/dealbook/trump-congress-financial-regulations.html_[https://perma.cc/326U-YF93].

227 U.S. DEP'T OF TREASURY, supra note 29, at 24.

228 See The Orderly Liquidation of Lehman Brothers Holdings Inc. Under the Dodd-Frank Act, 5 FDIC Q., no. 2, 2011, at 31.

229 See id. at 34. 
receiver could have helped to prevent a 'run on the bank' and the resulting financial instability." 230

While the FDIC acknowledges the importance of preventing a bank run and the necessity of establishing ex ante rules to do so, ${ }^{231}$ the lack of clarity regarding broker-dealer resolution under the OLA leaves broker-dealers vulnerable to runs. Clarity under the OLA and the Proposed Rules would go a long way toward preventing runs on broker-dealers.

In the Financial Crisis Inquiry Commission's ("the FCIC's") post-mortem report on the causes of the 2008 crisis, it noted that panic-induced runs consistently have played a part in precipitating financial crises. ${ }^{232}$ If there is a run, a firm may only be able to get low prices for assets and "large amounts of capital [could] disappear almost overnight." 233 Various economists have stressed the role of self-fulfilling prophecies as drivers of financial crises, and have identified both panic-induced behavior and rational concerns under imperfect information as causes of bank runs. ${ }^{234}$ The seminal paper by Douglas Diamond and Philip Dybvig focused on bank runs as causing real economic damage rather than simply reflecting underlying economic problems. ${ }^{235}$ The authors even went as far as to argue that "much of the economic damage in the Great Depression was caused directly by bank runs." 236 Thus, stability demands government action, such as

230 Id. at 48.

231 See id.

232 See FCIC REPORT, supra note 22, at 29.

233 Id. at 324.

234 See, e.g., Martin Schneider \& Aaron Tornell, Balance Sheet Effects, Bailout Guarantees and Financial Crises, 71 REv. ECON. STUD. 883 (2004); Charles W. Calomiris, Runs on Banks and the Lessons of the Great Depression, REG., Spring 1999, at 4.

235 See Douglas W. Diamond \& Philip H. Dybvig, Bank Runs, Deposit Insurance, and Liquidity, 91 J. PoL. Econ. 401 (1983). During a bank run, depositors rush to withdraw their deposits because they expect the bank to fail, in turn forcing a bank to liquidate many assets at a loss and to fail. See $i d$. at 401 .

236 Id. at 404. 
maintaining deposit insurance, to remove the incentive for depositors to withdraw their funds from banks. ${ }^{237}$

In 2007, it was not just large commercial banks that were subject to runs by creditors and depositors. Hedge funds suffered unprecedented runs and widespread redemptions by their investors as well, which forced the sale of an extraordinary amount of assets and "pummeled the markets." 238 For its part, Lehman experienced runs on its derivatives operations that played a role in its failure. ${ }^{239}$ Runs by repo lenders, hedge fund customers, and derivatives counterparties "devastated" Bear Stearns, which ultimately required a governmentbacked rescue. ${ }^{240}$ Per the FCIC, "Bear [Stearns]—solvent and profitable or not-could not [have] survive[d] a run that was fueled by fear and uncertainty about . . . the possibility of its insolvency." 241

To prevent a repeat of runs, policymakers should eliminate uncertainty regarding consumer and investor protections in order to maintain confidence and trust in the financial system. ${ }^{242}$ The FCIC described what it called the "classic setup for a run-"losses [are] likely, but nobody [knows] who [will] get burned." 243 The ambiguity of authority between the SIPC and FDIC under the OLA, the FDIC's considerable discretion under the Proposed Rules, and the uncertain status of those rules collectively place failing broker-dealers in this classic setup. If the OLA is triggered, it will be in the midst of a financial crisis, and losses are to be expected. But the current OLA framework invites unnecessary costs. Investors will not

237 Calomiris, supra note 234, at 5, 7 (describing common arguments linking deposit insurance to a decreased incentive to withdraw).

238 FCIC REPORT, supra note 22, at 361.

239 See id. at 343.

240 See id. at 280, 293.

241 Id. at 478 (dissenting statement of Peter J. Wallison \& Arthur F. Burns).

242 See Martin Brown et al., Understanding Bank-Run Contagion, 63 MGMT. SCI. 2272, 2280 (2017) (arguing uncertainty should be eliminated to prevent and contain runs and that ad hoc changes to the policies of safety nets should be avoided as they may be "counterproductive in mitigating the spread of runs").

243 FCIC REPORT, supra note 22, at 57. 
be sure of SIPA protections and will not be able to rely on precedent for assurance regarding SIPA's coverage of their investments. The possibility that the FDIC might exercise its discretion-whether arbitrarily due to oversight, mistakenly due to inadequate expertise, or deliberately due to public pressure-places investors in a pre-SIPA position where lack of confidence in the system and uncertainty about future losses may trigger runs on broker-dealers.

\section{B. Competing Priorities of FDIC and SIPC}

Certainty should not be underrated. Uncertainty and its resultant panic was one of the key drivers of the 2008 financial crisis. ${ }^{24}$ The growth of fintech will only add to the lack of clarity regarding what qualifies as customer property and who will get to decide this question. ${ }^{245}$ In a high-stress insolvency setting, where such determinations may have to be made quickly and on an ad hoc basis, predictability is of even greater benefit.

On top of the uncertainty created by the textual ambiguity of the OLA and the Proposed Rules, the FDIC's discretion causes further concern as fintech players enter the arena. The FDIC was created in the wake of commercial bank failures, and the SIPC was created in response to the failures of investment brokers. ${ }^{246}$ Accordingly, FDIC insurance protects the cash of bank customers, and SIPC coverage protects the securities of broker-dealer customers. SIPC coverage "for brokerdealer customers differs from [FDIC] insurance for bank depositors in the same way that investments differ from bank deposits." ${ }^{447}$ Bank deposits are a debt of the bank to the

244 See id. at 389 ("Panic and uncertainty in the financial system plunged the nation into the longest and deepest recession in generations.").

245 See supra Section II.C.2.

246 See supra notes 9-18 and accompanying text.

247 See The Securities Investor Protection Corporation: Past, Present, and Future: Hearing Before the Subcomm. on Capital Mkts. \& Gov't Sponsored Enters. of the H. Comm. on Fin. Servs., 112th Cong. 170 (2012) (statement of Ira D. Hammerman, Senior Managing Director \& General Counsel, Securities Industry \& Financial Markets Association) [hereinafter SIPC Hearings]. 
depositor, and are generally considered to be a safe use of funds. The FDIC insures the payment of bank deposits, including accrued interest. ${ }^{248}$ On the other hand, customers invest in securities to benefit from increases in their value, but also take the risk that the securities' value may drop. The SIPC, unlike the FDIC, is not a federal agency or a regulator. ${ }^{249}$ It does not protect investors from the risk of fluctuating market values, and does not bail out investors when the value of their investments fall. ${ }^{250}$ Where a clear line separates commercial and investment banks, what comes under the purview of the FDIC as opposed to the SIPC is clear. But as bank accounts become increasingly available to consumers through non-traditional providers-including fintech companiesclear lines continue to fall away, creating new opportunities for FDIC action and for its traditional role as an insurer of bank deposits to bias its view on broker-dealer customer property.

As briefly mentioned above, based on the narrow circumstances under which the OLA would be triggered, a determination on fintech-related customer assets may have to be made the first time OLA is invoked. As FDIC Chairman Jelena McWilliams has noted, fintech has made a dramatic change in the financial industry by providing broader access to banking services and changing how banks and broker-dealers interact with their customers. ${ }^{251}$ Technology giants have already entered the banking space, including Apple

248 See Deposit Insurance FAQs, FDIC (May 13, 2020), https://www.fdic.gov/deposit/deposits/faq.html [https://perma.cc/5Y9AB4BK].

249 See Investor FAQ, SIPC, https://www.sipc.org/for-investors/investor-faqs [https://perma.cc/5KYV-8HCC] (last visited July 1, 2020).

250 See What SIPC Protects, SIPC, https://www.sipc.org/for-investors/what-sipc-protects [https://perma.cc/MF2J-8ZZV] (last visited June 20, 2020).

251 See Jelena McWilliams, Chairman, Fed. Deposit Ins. Co., Keynote Remarks at the Brookings Institution: Brokered Deposits in the Fintech Age 3 (Dec. 11, 2019), https://www.brookings.edu/wp-content/uploads/2019/12/es_20191211_fintech_fdic_transcript.pdf [https://perma.cc/4JQ8-WMZA]. 
partnering with Goldman Sachs to offer iPhone users a credit card, ${ }^{252}$ Google partnering with Citibank and Stanford Federal Credit Union to offer bank accounts, ${ }^{253}$ and Uber partnering with Green Dot to offer bank accounts to its drivers. ${ }^{254}$ While fintech can offer benefits for investors and the financial services industry, it can also present challenges for investor protections. $^{255}$

One product that has increasingly been offered by fintech firms is the brokerage sweep account. Sweep accounts, which emerged in the early 2000s, are accounts into which brokerdealers make pre-arranged, automated transfers of un-invested funds from brokerage accounts. ${ }^{256}$ This prevents brokerage accounts from containing idle funds, since sweep accounts generate higher yields than leaving cash in brokerage accounts. ${ }^{257}$ Importantly, sweep accounts are also FDIC-

252 See Emily Flitter \& Jack Nicas, Goldman Sachs and Apple Plan to Offer a New Credit Card, N.Y. Times (May 10, 2018), https://www.nytimes.com/2018/05/10/business/apple-goldman-sachs-credit-card.html [https://perma.cc/HTJ4-5UAN].

253 See Paresh Dave \& Munsif Vengattil, Google Pay to Offer Checking Accounts Through Citi, Stanford Federal, REUTERs (Nov. 13, 2019), https://www.reuters.com/article/us-google-finance/google-pay-to-offerchecking-accounts-through-citi-stanford-federal-idUSKBN1XN1IQ [https://perma.cc/ET6F-57WR].

254 See Press Release, Green Dot Corp., Green Dot and Uber Announce "Uber Checking by GoBank" (Mar. 17, 2016), http://ir.greendot.com/newsreleases/news-release-details/green-dot-and-uber-announce-uber-checkinggobankr/ [https://perma.cc/3NXY-5DJJ].

255 See Press Release, FINRA, FINRA Requests Comment on Financial Technology Innovation in the Broker-Dealer Industry (July 30, 2018), https://www.finra.org/rules-guidance/notices/special-notice-07302018 [https://perma.cc/F7WT-44LS] (noting that fintech can "present investor protection concerns where the safeguards of the securities laws are not respected").

256 See McWilliams, supra note 251, at 3. See also 12 C.F.R. § 360.9(b)(3) (2018).

257 See James Chen, Sweep Account, InVestopedia (Sept. 25, 2019), https://www.investopedia.com/terms/s/sweepaccount.asp [https://perma.cc/PQS9-UYRU] ("Sweep accounts try to minimize idle cash drag by capitalizing on the immediate availability of high-interest accounts."). 
insured. ${ }^{258}$ However, while a SIPC member may sweep idle balances into a sweep account eligible for FDIC insurance, the swept balances will typically not be covered by the SIPC. ${ }^{259}$ Thus, in an OLA liquidation, there may be a dispute as to whether FDIC or SIPC coverage applies. Because SIPA only covers cash deposited for the purpose of purchasing securities, ${ }^{260}$ there may be a moment where un-swept cash is ineligible for both FDIC and SIPC coverage. Investors, however, may be expecting both forms of coverage. One solution, made possible by the ambiguity of the OLA and the Proposed Rules, is for the FDIC to overrule a SIPC determination that the idle cash does not constitute customer property. In effect, the FDIC could determine that the sweep offering-which is widely marketed as being FDIC-insured-is in fact covered by SIPA. Given the limited judicial review available under the OLA, it does not appear that the SIPC would have any legal redress for such a determination.

One example is Robinhood Markets Inc. ("Robinhood"), which started as an online brokerage firm targeting young, first-time investors. ${ }^{261}$ The company originally offered commission-free trades through a user-friendly smartphone app,

258 See Office of Inv'r Educ. \& Advocacy, Investor Bulletin: Bank Sweep Programs, U.S. SEC. \& Exchange Commission (June 4, 2014), https://www.sec.gov/oiea/investor-alerts-bulletins/ib_banksweep.html [https://perma.cc/89J5-K5PX] ("Cash swept into deposit accounts through bank sweep programs is covered by FDIC insurance up to the $\$ 250,000$ limit per customer at each FDIC-Insured bank that participates in the bank sweep program.").

259 For instance, Fidelity's description of its FDIC-Insured Deposit Sweep Program includes a footnote clarifying that " $[t]$ he cash balance in the core position is swept to an FDIC-insured interest-bearing account at a Program Bank. The deposit at the Program Bank is not covered by [SIPC]." FDIC-Insured Deposit Sweep Program, FIDELITY, https://accountopening.fidelity.com/ftgw/aong/aongapp/fdicBankList [https://perma.cc/3HNTLGNG] (last visited June 20, 2020).

260 See 15 U.S.C. $\S 78 l l l(2)(B)(i)(2018)$.

261 See, e.g., William Alden, Financial Start-Ups Aim to Court the AntiFinance Crowd, N.Y. TIMES (Dec. 22, 2014), https://dealbook.nytimes.com/2014/12/22/financial-start-ups-aim-to-court-the-anti-financecrowd/ [https://perma.cc/Y76C-ZW4G]. 
and was able to amass over six million users. ${ }^{262}$ After its success in the brokerage space, Robinhood, a SIPC member, announced that it would offer no-fee checking and savings accounts, claiming funds in the accounts were covered by the SIPC. ${ }^{263}$ But Robinhood had not contacted SIPC prior to its announcement of the accounts, ${ }^{264}$ and the SIPC quickly clarified that the accounts would not be eligible for SIPA protection. ${ }^{265}$ The funds in those accounts would not be there "for the purpose of purchasing securities," and thus would not meet the criteria for customer property under SIPA. ${ }^{266}$ In the midst of the media attention resulting from this correction of the SIPC, Robinhood cancelled the rollout of the accounts. ${ }^{267}$ Not to be defeated, it made a second attempt at offering the banking accounts ten months later-this time structuring the

262 See Maggie Fitzgerald, Start-up Robinhood Tops 10 Million Accounts Even As Industry Follows in Free-Trading Footsteps, CNBC (Dec. 4, 2019), https://www.cnbc.com/2019/12/04/start-up-robinhood-tops-10-million-accounts-even-as-industry-follows-in-free-trading-footsteps.html [https://perma.cc/9FTU-KFGA].

263 See Janna Herron, Cash Deposited in Robinhood's 3\% Checking and Savings Isn't Insured, SIPC Says, USA TODAY (Dec. 19, 2018), https://www.usatoday.com/story/money/2018/12/14/robinhood-checkingand-savings-features-not-insured-says-sipc/2310208002/ [https://perma.cc/BF2H-Q9TP].

264 Liz Moyer \& Kate Rooney, Robinhood Didn't Give Key Industry Watchdog a Heads-up About the Launch of Its Free Checking Account, CNBC (Dec. 14, 2018), https://www.cnbc.com/2018/12/14/sipc-chief-raisesconcerns-to-sec-about-robinhoods-free-checking-accounts.html [https://perma.cc/K4UP-PSMK].

265 Jeff Kauflin, SIPC Head Has Concerns About Robinhood's Checking and Savings Products, Forbes (Dec. 14, 2018), https://www.forbes.com/sites/jeffkauflin/2018/12/14/sipc-head-has-concerns-about-robinhoods-checking-and-savings-products/\#1f2e7b016827 [https://perma.cc/QJ84-Q6TJ].

266 See 15 U.S.C. $\S 78 l l l(2)(B)(\mathrm{i})$.

267 See Ben Walsh, Brokerage Robinhood Tries Again in Push into Banking, BARRON's (Oct. 8, 2019), https://www.barrons.com/articles/brokerage-robinhood-banking-account-sipc-fdic-cash-management-51570565280 [https://perma.cc/MC3V-GMCX]. 
offering as a sweep, and announcing that the accounts would be insured by the FDIC. ${ }^{268}$

Ultimately Robinhood cancelled the offering, ${ }^{269}$ but gave us a glimpse of fintech firms entering the hybrid brokerage-banking space and the already complicated area of sweep accounts. While regulators corrected Robinhood prospectively, how might the FDIC and SIPC have responded were a similar mistake discovered during a time of crisis? There would be considerable public pressure to save retail investors who believed that their checking and savings accounts enjoyed SIPA protection, and the FDIC would be under equally great pressure to protect accounts that, in name and practice, are equivalent to those that it has traditionally insured.

Robinhood is just one example of a fintech company testing the line between brokerage and retail-banking services. Barney Frank, the former Congressman from Massachusetts and a key architect of Dodd-Frank, in discussing aspects of Robinhood's proposed offering, noted that "[i]f there's any uncertainty about regulatory protection, there is serious potential for people to be misled." 270 Technological disruption increases the need for the SIPC and FDIC, along with other agencies and regulators, to adapt and maintain investor trust and certainty. Effective financial regulation is a means of supporting trust in the financial system while emerging technologies innovate within the financial services industry and potentially raise new financial stability risks. ${ }^{271} \mathrm{~A}$ clear and predictable legal framework increases investors' confidence in the functioning of financial markets and the efficacy of the statutory protections afforded to them. Ambiguity regarding agency

268 See Lisa Beilfuss, Robinhood Joins the Online Cash War, WALL ST. J. (Oct. 8, 2019), https://www.wsj.com/articles/robinhood-joins-the-onlinecash-war-11570556839 [https://perma.cc/5RDT-LW4Y].

269 See Nicholas Megaw, Monzo Turns to Visa Exec to Lead US Push, Fin. Times (Dec. 2, 2019), https://www.ft.com/content/3f395284-1514-11ea9ee4-11f260415385 [https://perma.cc/JW4B-HY76].

270 See Moyer \& Rooney, supra note 264.

271 Dong He et al., Fintech and Financial Services: Initial Considerations 14-15 (Int'l Monetary Fund, Staff Discussion Note No. 17/05, 2017), https://www.imf.org/ /media/Files/Publications/SDN/2017/sdn1705.ashx [https://perma.cc/87QB-8ZAW]. 
involvement in times of crisis creates uncertainty and threatens financial stability. ${ }^{272}$ As fintech companies develop hybrid offerings, boundaries are blurring among entities, activities, and jurisdictions, and the role of the broker-dealer may become increasingly complicated. ${ }^{273}$ Dodd-Frank skews in favor of retail bank accounts, and, at its core, the FDIC's role is to protect bank deposits. ${ }^{274}$ Where a broker-dealer comes under the purview of both the SIPC and FDIC, the FDIC has an incentive to protect retail bank accounts at the expense of brokers or investors. ${ }^{275}$

In regulating brokered deposits such as sweep accounts, the FDIC has certain stated goals. ${ }^{276}$ First, the FDIC aims to minimize the risk to its deposit insurance fund. 277 This can be done by changing the FDIC's deposit insurance assessment pricing or by redefining the scope of FDIC coverage. ${ }^{278}$ Unfortunately, the FDIC can also protect its deposit insurance fund by using its discretion to overrule SIPC determinations in order to force SIPC coverage, effectively protecting its own fund at the expense of the SIPC Fund. Second, the FDIC aims to

272 See generally JACQUES DE LAROSIÈRE ET AL., THE High-LEVEL GrouP ON FinANCIAL SuPERVISION IN THE EU (2009), https://ec.europa.eu/economy_finance/publications/pages/publication14527_en.pdf [https://perma.cc/6VZ3-DTZ5].

273 See He et al., supra note 271 , at 5-6.

274 See Jeffrey N. Gordon \& Christopher Muller, Confronting Financial Crisis: Dodd-Frank's Dangers and the Case for a Systemic Emergency Insurance Fund, 28 YALE J. REG. 151, 185 (2011).

275 See id. at 185-86 (describing the FDIC's historical use of "open bank" assistance powers and the possibility of the FDIC exercising its discretion to disfavor certain creditor claims). For example, if a commercial bank held an account at a broker-dealer that is liquidated under OLA, the FDIC, to mitigate against the bank's failure, may be incentivized to exercise its discretion over customer property determinations to ensure the bank receives maximal recovery, perhaps at the expense of other investors. See Thomas W. Joo, A Comparison of Liquidation Regimes: Dodd-Frank's Orderly Liquidation Authority and the Securities Investor Protection Act, 6 Brook. J. CorP. Fin. \& CoM. L. 47, 65 (2011).

276 See McWilliams, supra note 251, at 7 . While the speech lists four goals, this Note discusses only the two that are the most relevant.

277 See id.

278 See id. at 7-8. 
encourage innovation in the way modern consumers access banking services. ${ }^{279}$ One of the ways to accomplish this is to expand the partnerships between banks and fintech companies. ${ }^{280}$ Given the FDIC's broad approach to regulation that "remove[s] regulatory hurdles to innovative partnerships between banks and nonbanks," we will likely see further fintech entrants into the sweeps arena, and, perhaps, even Robinhood 3.0 .

\section{How Much Discretion is Too Much Discretion?}

The FDIC has considerable discretion under the OLA. ${ }^{281}$ One of the main criticisms of the OLA is that it gives the FDIC too much discretion without meaningful judicial review, and is thus "unpredictable, inconsistent with traditional notions of due process . . . and possibly unconstitutional." 282 Critics argue that the OLA enables-rather than prevents-future bailouts funded by taxpayers ${ }^{283}$ because the FDIC has discretion to decide when and how to resolve distressed financial firms and

279 Id. at 4.

280 See Davis Polk \& Wardwell LLP, Encouraging InNovation: BroKered Deposits-What Fintechs Need to Know to Partner With Banks Under the FDIC's Proposed Regulations 4 (2020), https://www.davispolk.com/files/2020-01-16_encouraging_innovation_brokered_depositswhat_fintechs_need_to_know_to_partner_with_banks_un-

der_the_fdics_proposed_regulations.pdf [https://perma.cc/TR7G-HY7S].

281 See Gordon \& Muller, supra note 274, at 191; Joo, supra note 275, at $64-66,68$. Once the FDIC is appointed receiver of a failing firm under OLA, it can take over the assets and operate the financial company "with all of the powers of the members or shareholders, the directors, and the officers of the covered financial company.” 12 U.S.C. $§ 5390(a)(1)(B)(i)(2018)$; See also Kwon-Yong Jin, How to Eat an Elephant: Corporate Group Structure of Systemically Important Financial Institutions, Orderly Liquidation Authority, and Single Point of Entry Resolution, 124 YALE L.J. 1746, 1754 (2015) (describing the FDIC as operating and liquidating a firm under OLA with "near-complete freedom").

282 Randall D. Guynn, Framing the TBTF Problem: The Path to a Solution, in Across the Great Divide: New Perspectives on the Financial CRIsIs 281, 287 (Martin Neil Baily \& John B. Taylor eds., 2014).

283 See SKEEL, supra note 27. 
may discriminate among similarly situated creditors. ${ }^{284}$ In the Treasury Report on the OLA, the Treasury Department specifically made recommendations to address the FDIC's broad discretion to treat similarly situated creditors differently "without a clearly defined standard to protect disfavored creditors against arbitrary FDIC action." 285

The Proposed Rules extend the FDIC's discretion with respect to customer asset determinations, even though the SIPC has far more experience making such determinations. The FDIC's discretion over the matter places these determinations in less sure hands, and creates an avenue for the FDIC to overrule determinations consistent with SIPA in order to further its own competing interests. The determination of customer property is quite different from determinations that require a broad view, such as whether a firm's failure would have serious adverse effects on financial stability. Determining what counts as "customer property" is a far more narrow, technical exercise based on statutory interpretation and informed by abundant case law and SIPC rulings. ${ }^{286}$ As the Treasury

284 The OLA explicitly authorizes the FDIC to treat similarly situated creditors differently if the FDIC makes a general determination that such favored treatment is "necessary to maximize the value of the assets of the covered financial company." 12 U.S.C. $\$ 5390(\mathrm{~b})(4)(\mathrm{A})$.

285 U.S. DEP'T OF TREASURY, supra note 29 , at 32.

286 See, e.g., In re Stalvey \& Assocs., 750 F.2d 464, 468 (5th Cir. 1985) (stating the term " "[c]ustomer' . . . is a statutorily defined term of art" that is "an integral part of a comprehensive statutory scheme governing the rights of creditors and brokers"); SEC v. F.O. Baroff Co., 497 F.2d. 280, 282 n.2 (2d Cir. 1974) ("[SIPA] contemplates that a person may be a "customer" with respect to some of his claims for cash or shares, but not with respect to others.”); In re New Times Sec. Servs., Inc., 463 F.3d 125, 130 (2d Cir. 2006) ("[C] ustomer status in the course of some dealings with a broker will not confer that status upon other dealings, no matter how intimately related, unless those other dealings also fall within the ambit of the statute."); SEC v. Packer, Wilbur \& Co., 498 F.2d 978 (2d Cir. 1974) ("If equity were the criterion, most customers . . . would be entitled to reimbursement for their losses. Experience, on the other hand, counsels that they will have to settle for much less.”); In re Bevill, Bresler \& Schulman Asset Mgmt. Corp., 67 B.R. 557, 599 (D.N.J. 1986) ("[SIPA's] purpose was to extend a measure of special protection for the investments of those parties who fall within the statutory definition of the 'customer."'); In re Lehman Bros. Inc., 474 B.R. 139, 146 (Bankr. S.D.N.Y. 2012) (claims for "soft dollar" commission credits 
Report on the OLA observed, the FDIC's experience in adjudicating claims of insured depository institutions is not necessarily applicable to the OLA, especially given the different balance sheets of depository institutions within the FDIC's traditional purview and those of OLA-covered financial companies. ${ }^{287}$

In response to criticism of the FDIC's discretion, proponents maintain that the OLA is only a fallback or last resort when other resolution regimes fail. ${ }^{288}$ Indeed, the Treasury Report on the OLA recommended the OLA's retention only "as an emergency tool for use in extraordinary circumstances." 289 But any liquidation under the OLA would be extraordinary. The OLA's invocation necessarily accompanies an emergency, which may give political or financial exigencies greater weight, particularly where statutory authority and agency rules are ambiguous or unclear. ${ }^{290}$ Under such emergency circumstances, characterized by political constraints, public pressure, and widespread uncertainty, there would be greater incentives for the FDIC to wield its discretion to overrule SIPC determinations of customer property. ${ }^{291}$

are not customer claims under SIPA); In re Adler Coleman Clearing Corp., 216 B.R. 719 (Bankr. S.D.N.Y. 1998) (claims for cash in clearing account were not customer claims where the account was never used to buy or sell securities); SEC v. White \& Co., 406 F. Supp. 806 (E.D. Mo. 1975) (bank's claim arising from erroneous payment of cash was not a customer claim under SIPA); In re Hanover Square Sec., 55 B.R. 235, 239 (Bankr. S.D.N.Y. 1985) (stating a fiduciary relationship is "the hallmark of the 'customer'broker transaction"); In re First Interregional Equity Corp., 290 B.R. 265 (Bankr. D.N.J. 2003) (claimant that lent securities to debtor in return for enhanced interest payments was not a customer under SIPA).

287 See U.S. DEP'T OF TREASURY, supra note 29, at 35.

288 See, e.g., Maciuch, supra note 98, at 279-80.

289 U.S. DEP'T OF TREASURY, supra note 29, at 31.

290 See Joo, supra note 275, at 52 ("[T] he executive branch regularly claims and exercises extraordinary powers when it perceives an 'emergency,' and Congress tends to go along.").

291 See, e.g., Who is Too Big to Fail: Does Title II of the Dodd-Frank Act Enshrine Taxpayer-Funded Bailouts?: Hearing Before the Subcomm. on Oversight \& Investigations of the H. Comm. on Fin. Servs., 113th Cong. 8-9 (2013) (statement of John. B. Taylor, Professor, Stanford University) ("There will be every incentive for the FDIC to provide additional funds to some creditors, additional funds over and above what they would get under 
One example of how public pressure can exert influence on customer property determinations is the Stanford Group Ponzi episode. In that situation, victims of financial fraud had little means of compensation other than SIPA, and the SEC attempted to "twist] [the] SIPC's arm" to obtain a favorable customer determination. ${ }^{292}$ The SIPC had determined that SIPA did not cover certain investor losses from certificates of deposits issued by a non-SIPC member, ${ }^{293}$ but faced enormous social and political pressure-both from a public campaign for victim compensation and a senatorial threat to block nominees to the SEC. ${ }^{294}$ Under such pressure, the SEC filed suit pursuant to its authorization under SIPA, seeking to compel the SIPC to provide SIPA-based compensation for investor losses. ${ }^{295}$ Despite the SIPC's insistence that SIPA did not cover those losses-and even the SEC's tacit endorsement that the SIPC was correct ${ }^{296}$ - the only realistic prospect for

a normal bankruptcy or in the marketplace.”); Eric A. Posner \& Adrian Vermeule, Crisis Governance in the Administrative State: $9 / 11$ and the Financial Meltdown of 2008, 76 U. CHI. L. REV. 1613, 1614 (2009) ("Political conditions and constraints, including demands for swift action by an aroused public, massive uncertainty, and awareness of their own ignorance leave rational legislators and judges no real choice but to hand the reins to the executive and hope for the best.").

292 See Oversight of the Securities Investor Protection Corporation: Hearing Before the Subcomm. on Secs., Ins., \& Inv. of the S. Comm. on Banking, Hous. \& Urban Affairs, 114th Cong. 11 (2016) (statement of Sigmund S. Wissner-Gross, Esq., Senior Partner, Brown Rudnick LLP).

293 See SEC v. Sec. Inv'r Prot. Corp., 872 F. Supp. 2d 1, 5-8 (D.D.C. 2012). For further background on the Stanford Financial Group Ponzi scheme, see Anita K. Krug, Escaping Entity-Centrism in Financial Services Regulation, 113 CoLUM. L. REV. 2039, 2080-87 (2013).

294 See Jessica Holzer, Senator to Block SEC Nominees Until Stanford Ruling Issued, WALL ST. J. (June 14, 2011), https://www.wsj.com/articles/SB10001424052702303848104576385742205738426 [https://perma.cc/7XWR-WJWN].

295 See Sec. Inv'r Prot. Corp., 872 F. Supp. $2 \mathrm{~d}$ at 2.

296 See Office of Inspector Gen., U.S. Sec. \& Exch. Comm’n, OIG-560, InVEstigation of CONFLICT of INTEREST ARISING FROM ForMER GENERAL Counsel's Participation in Madoff-Related Matters 112 (2011), https://www.sec.gov/foia/docs/oig-560.pdf [https://perma.cc/W572-SDJ3] (noting the testimony of former SEC General Counsel David Becker, who opined that "SIPA, the statute, did not cover the Stanford situation"). 
the customers to get at least some of their money back appeared to be SIPA. ${ }^{297}$ Ultimately, though the courts were "truly sympathetic" to the plight of the victims, they denied relief, and the SIPC's determination of customer claims prevailed. ${ }^{298}$ It was only after years of extensive negotiation and litigation, however, that the SIPC was able to ensure its determinations under SIPA would stand. ${ }^{299}$

The situation would be quite different in a liquidation under the OLA. Given the ambiguous split of authority between the FDIC and SIPC and the broad discretion of the FDIC to treat similarly situated creditors differently and seemingly overrule SIPC determinations, the FDIC could make customer claim determinations against the objections of the SIPC without having to litigate its case. Further, the FDIC's actions would be subject to far less judicial review. While a SIPA liquidation occurs within the jurisdiction of a bankruptcy court, ${ }^{300}$ under the OLA, the FDIC is a statutory receiver not subject to direct court supervision, and thus its discretion can only be cabined by the Agencies' rules. ${ }^{301}$ Under the OLA and the Proposed Rules, the FDIC has the leeway to effectively take whatever position it wants. ${ }^{302}$

297 See Peter J. Henning, Compensating Stanford's Investors, N.Y. Times (June 20, 2011), https://dealbook.nytimes.com/2011/06/20/compensating-stanfords-investors/ [https://perma.cc/AH7U-54KR] (noting that the SEC was pushing for Stanford's customers to be treated as brokerage customers by SIPC because, if they were so treated, they "could get at least some of their money back").

298 See SEC v. Sec. Inv'r Prot. Corp., 758 F.3d 357, 369 (D.C. Cir. 2014).

299 See Jordan D. Maglich, SEC Files Lawsuit Against SIPC in Dispute Over Coverage of Stanford Ponzi Scheme, LexisNexis LEgal NewsRoom (Dec. 13, 2011), https://www.lexisnexis.com/LegalNewsRoom/securities/b/securities/posts/sec-files-lawsuit-against-sipc-in-dispute-over-coverage-of-stanford-ponzi-scheme [https://perma.cc/2Q3Y-7N5C]; SEC v. Sec. Inv'r Prot. Corp., 872 F. Supp. 2d 1 (D.D.C. 2012), aff'd, 758 F.3d 357, 369 (D.C. Cir. 2014).

30015 U.S.C. $\S 78$ eee(b)(4) (2018).

301 See Joo, supra note 275 , at 64.

302 Note that although the Proposed Rules allow a claimant to seek de novo judicial review of any claim that is disallowed by the FDIC, there is no such standing for SIPC to challenge FDIC determinations, even if they overrule SIPC's own determinations. Covered Broker-Dealer Provisions Under 
Public outcry, political posturing, inter-agency disputes, and perhaps sheer sympathy, can place enormous pressure on SIPC determinations. Admittedly, these determinations may lead to unfortunate results. But one can remain sympathetic while questioning the wisdom of agency discretion without limits, especially where it may be extremely difficult for an agency to resist public pressure or the exigencies of financial stability, and where predictability is of great value. Certainty regarding loss allocation and customer protections limits the effects of financial crises and facilitates successful insolvency proceedings. Having built up almost fifty years of experience in making customer property determinations, the SIPC-rather than the FDIC, which has no experience with brokerdealers-should make final determinations of customer property under the OLA. Without Gramm-Leach-Bliley, it would be clear that the FDIC handles retail banks, and that the SIPC handles broker-dealers. But the OLA and the Proposed Rules seem to have created a world where the FDIC is responsible for retail banks and retail accounts, as well as making decisions about customer property. There is no good reason for this, and no good reason for giving the FDIC nearly unlimited discretion in making these decisions.

Further, market participants do not like uncertainty. Considering the increase in hybrid brokerage-banks due to innovations in the fintech sector, the systemic risk created by fintech, and the increasing amount of new investors participating in the markets, there is additional incentive to create certainty and to leave such decisions to a body with a particular expertise. Giving investors more certainty as to which of their assets are protected would mitigate potential runs on broker-dealers that could trigger failures. Moreover, the mere fact that the FDIC does have discretion over the SIPC's determinations is enough to cause fear and anxiety among customers. The important fact is not when or why the FDIC would use such discretionary power, but that they have such power in the first place.

Title II of the Dodd-Frank Wall Street Reform and Consumer Protection Act, 81 Fed. Reg. 10,798, 10,806 (proposed Mar. 2, 2016) (to be codified at 12 C.F.R. pt. 380 and 17 C.F.R. pt. 302). 


\section{CONCLUSION}

"[M]arkets run as much on confidence as they do on capital." 303 The SIPC is "not a regulator in any way, shape, or form," and, unlike the FDIC, is not an insurer. ${ }^{304}$ The SIPC, however, is an expert on customer property determinations. It has built a fifty-year track record through experience and litigation of such determinations, which not only gives investors confidence as to their protections under SIPA, but also positions the SIPC well to make a quick determination during an immense crisis.

The FDIC's discretion breeds uncertainty and fear because it is unclear how it will be used. Under the OLA, the FDIC already has considerably broad discretion "to pursue the vague goal of financial stability." 305 Rather than bringing clarity, the Proposed Rules, in giving FDIC discretion to overrule SIPC determinations, leave the resolution process openended. If called upon to make customer property determinations, one would have to fit a decades-old statute to a more recent financial arrangement, and one would have to do it fast.

303 See SIPC Hearings, supra note 247, at 3 (statement of Rep. Carolyn B. Maloney).

304 Id. at 23 (testimony of Stephen P. Harbeck, President \& Chief Executive Officer, Securities Investor Protection Corporation).

305 Joo, supra note 275, at 75. See also 12 U.S.C. § 5384(a) (2018). 